\title{
MATRIZ ENERGÉTICA ELÉTRICA BRASILEIRA: CONSIDERAÇÕES SOBRE AS FONTES QUE A COMPÕEM EM UMA NOÇÃO AMPLA DE SUSTENTABILIDADE
}

\section{BRAZILIAN ELECTRICAL ENERGY MATRIX: CONSIDERATIONS ON THE SOURCES THAT MAKE UP IN A WIDE NOTION OF SUSTAINABILITY}

\author{
Igor Sporch da Costa ${ }^{1}$ \\ Julia Barros Valadão²
}

\section{Resumo}

As discussões sobre a produção energética se pautam, em regra, por uma lógica fundada no custo de implantação/manutenção e o potencial energético a ser gerado. Todavia, a emergência da questão ambiental obrigou que se agregassem à lógica tradicional, outros temários que variam da relativização da tutela ambiental - considerada um elemento acessório a ser contabilizado nos custos - ao desenvolvimento de novas fontes de energia. É nesta segunda linha de consequências que o tema das energias renováveis ganha importância e, paulatinamente, obriga que, no centro do debate, inclua-se uma ideia ampliada de sustentabilidade que considere os elementos econômicos, técnicos, ambientais e, também, os impactos sociais decorrentes da produção e funcionamento destes modais. Assim, este ensaio objetiva apontar como a sobredita ampliação semântica se apresenta determinante na política energética brasileira. Para tanto, a análise empreendida empregou o método dedutivo-interpretativo, tendo como principais procedimentos metodológicos, a pesquisa bibliográfica e documental, constituindo-se em fontes primárias, as fontes normativas e os dados técnicos sobre o potencial, o processo de produção e os impactos das várias fontes de energia integrantes da matriz nacional, e, por secundários, os apontamentos doutrinários concernentes aos temas abordados. Dessa forma, como principal resultado obtido, tem-se que a ampliação do conceito de sustentabilidade implica a inserção de inúmeras variáveis que, ao complexificar o processo decisório, majora a possibilidade de efetividade da política energética brasileira e de outras a ela relacionadas.

Palavras-chave: Sustentabilidade; composição da matriz energética brasileira; energias renováveis; política energética; impactos.

\begin{abstract}
Discussions on energy production are guided, as a rule, by a logic based on the cost of deployment / maintenance and the potential energy to be generated. However, the emergence of the environmental question forced the aggregation to traditional logic, other subjects ranging from relativity of environmental protection - considered an accessory element to be accounted for in costs to the development of new energy sources. It is this second line of consequences that the subject of renewable energy becomes important and, gradually, in the center of the debate, requires the inclusion of an enlarged idea of sustainability that considers the economic elements, technical,

\footnotetext{
${ }^{1}$ Mestre em Direito Administrativo pela Faculdade de Direito da Universidade Federal de Minas Gerais - UFMG, Doutorando em Direito da Cidade na Universidade do Estado do Rio de Janeiro - UERJ. Professor da Universidade Estadual de Ponta Grossa - UEPG/PR. E-mail: igorsporch@yahoo.com.br

2 Arquiteta, Mestre em Engenharia Civil pela Universidade Federal de Viçosa. Professora nos cursos de Arquitetura e Urbanismo, Engenharia Elétrica e Engenharia de Produção da Faculdade Educacional de Ponta Grossa. E-mail: juliavaladao@yahoo.com.br
} 
environmental and also social impacts from the production and operation of these modes. Thus, the study aims to show how the aforesaid semantic expansion appears decisive in the Brazilian energy policy. Therefore, the analysis has used the deductive-interpretative method, the main methodological procedures, bibliographical and documentary research, thus becoming primary sources, regulatory sources and technical data on the potential, the production process and the impacts the various sources of energy members of the national matrix, and, secondary, doctrinal notes concerning the topics covered. Thus, the main result, it follows that the expansion of the concept of sustainability implies the inclusion of numerous variables that by complexifying the decision-making process, the possibility of effectiveness of the Brazilian energy policy and other related to it.

Keywords: Sustainability; composition of the Brazilian energy matrix; renewable energy; energy policy; impacts.

\section{INTRODUÇÃO}

É difundida a percepção de que a política energética é um tema restrito às Ciências Exatas e Econômicas, em que as primeiras se ocupariam dos elementos relativos à produção/geração/implantação do empreendimento, enquanto as segundas cuidariam da alocação de recursos financeiros para o seu custeio e projetariam o período de retorno dos investimentos. Embora tais operações sejam complexas, paulatinamente, constata-se que a lógica inerente à forma de abordar a questão é reducionista, porquanto desconsidera inúmeras variáveis determinantes à consecução dos fins da aludida política pública.

Esta percepção inicia um processo de reconhecimento de pontos de contato e interseções da política energética com outras searas, como a social e a ambiental. Assim, ao lado da sobredita lógica - ínsita à definição da matriz energética, dos tipos a serem desenvolvidos e das tecnologias empregadas - outras se mostram relevantes como, a redução e a racionalização do consumo, os efeitos das políticas de geração em outras políticas púbicas - contribuindo à realização de seus objetivos ou obstaculizando-os - e os impactos destas ações no processo de geração.

Vê-se, assim, que tais interfaces implicam que, no processo decisório relativos à política energética, a sustentabilidade - vista numa perspectiva ampliada que abarque as feições econômica, técnica, social e ambiental - ocupe o papel central, notadamente no que concerne à diversificação da matriz energética brasileira, e à produção de energia a partir de fontes renováveis. Dessa forma, este ensaio objetiva demonstrar como a ampliação da noção de sustentabilidade fornece variáveis a serem consideradas no citado processo decisório e, para tanto, aplica nessa investigação um raciocínio dedutivo-interpretativo, subsidiado por uma pesquisa bibliográfica e documental - cujas fontes secundárias se constituem em apontamentos teórico-doutrinários e as primárias em textos normativos e dados técnicos sobre o potencial, o processo de geração e consumo e os impactos positivos e negativos das várias fontes que compõem a matriz energética elétrica brasileira. 
Para isso, este ensaio foi dividido em quatro seções. Inicialmente, esta introdução, que apresenta os elementos teóricos que permearam a investigação e os principais elementos metodológicos que a viabilizaram. Em seguida, apresenta-se como a ideia de sustentabilidade, hodiernamente, conjuga questões técnicas, econômicas, ambientais e sociais, e que, apesar das dificuldades para o reconhecimento de sua carga normativa, podem-se dela extrair balizamentos referentes tanto à racionalização do uso/consumo de recursos e ao delineamento das diversas ações estatais incidentes sobre o meio. Na seção seguinte é descrita a matriz energética elétrica brasileira, enfatizando-se a sua composição, o processo de produção de cada um dos tipos que a compõe, apresentando-se alguns dos riscos inerentes a cada uma das suas espécies. Enfim, são retomados os principais pontos examinados, conjugando-se os elementos técnicos descritos na seção anterior com o cabedal teórico-analítico construído, de forma a demonstrar como todas as variáveis decorrentes da noção de sustentabilidade complexificam o processo decisório atinente à política energética brasileira, o que, longe de obstaculiza-lo, amplia as condições de cumprimento das finalidades desta e das outras políticas públicas a ela relacionadas.

Assim, sem esgotar o tema, a proposta, deste ensaio é outra. Numa perspectiva interdisciplinar, centra-se no fomento da discussão a partir do reconhecimento das interfaces entre as diversas políticas públicas abordadas, apresentando elementos concernentes ao reconhecimento de sua interdependência e que, ao mesmo tempo, auxiliem na construção de índices que, ao objetivar a noção ampliada de sustentabilidade, contribuam à sua normatividade e à efetividade da política energética pátria. Feitas tais ilações, ao estudo.

\section{SUSTENTABILIDADE: ENTRE EFICIÊNCIA ECONÔMICA, DESENVOLVIMENTO SOCIAL E TUTELA AMBIENTAL}

Uma das características perceptíveis na linguagem comum é o caráter plurissignificativo dos vocábulos. Seus sentidos são estabelecidos historicamente, mediante operações de agregação ou, até mesmo, modificação de significados, o que, porém, não prejudica a compreensão das ideias que se quer compartilhar, pois diversos mecanismos linguísticos foram desenvolvidos para viabilizar a comunicação. Entre estes, a compreensão do vocábulo no contexto do diálogo, a entonação, a colocação frasal e o emprego de outras palavras que especifiquem aquela que contém o sentido central da ideia que se quer exprimir. ${ }^{3}$

\footnotetext{
3 Tais mecanismos possibilitam que a comunidade dos falantes contorne os aludidos problemas de compreensão, de forma que, os hodiernos ouvintes entendem o que as pretéritas gerações desejaram expressar e consigam identificar as aludidas agregações/modificações semânticas.
} 
A linguagem técnica, ao cuidar da elaboração teórica, de sua comunicação à comunidade científica, vale-se dos mesmos vocábulos empregados na linguagem corriqueira. Entretanto, devido à necessidade de precisão terminológica - seja para evitar equívocos, seja pela busca da objetividade, ou pelo desejo da infalibilidade - a linguagem técnica atribui aos vocábulos corriqueiros significados próprios, ou seleciona um dos sentidos comuns como designador daquele que a palavra possuirá naquele campo. Tal como na linguagem corriqueira, também a evolução exige, por vezes, a criação de vocábulos e, em outras, a atualização de significados tradicionais, o que, em regra, dá-se pela adjetivação, pois, como as ideias, geralmente, são transmitidas de forma escrita, expedientes como a entonação, que, próprios da expressão falada, tornam-se inaplicáveis.

Este grau de especificação possibilita, por um lado, que "falantes da mesma linguagem técnica", ainda que de idiomas diversos, consigam se comunicar; e, lado outro, dificulta que falantes do mesmo idioma corriqueiro, mas "falantes de linguagens técnicas distintas" não se compreendam, afinal, podem atribuir significados diversos ao mesmo vocábulo ou faltar-Ihes pressupostos técnicolinguísticos comuns ou uma metalinguagem que viabilize o diálogo. Se, no passado, esta falta de comunicação não se constituia em um entrave diante de uma racionalidade linear marcada pelo isolamento dos campos de conhecimento, tais obstáculos surgem e se agudizam quando se reconhecem problemas/objetos comuns a várias disciplinas, ou quando se constata a complexidade do real e o caráter parcial/provisório das soluções científicas. ${ }^{4}$ Estes óbices ganham maior relevância quando se constata que os responsáveis por tomadas de decisões públicas ou particulares se baseiam em resultados apresentados por especialistas de diversos campos do saber, catalisando os impactos de tais construções científicas na vida dos demais indivíduos.

O vocábulo "desenvolvimento" ilustra estas afirmações. Vulgarmente ligado às ideias de "explicação", "minúcia" e "crescimento", ao ingressar no campo de estudos econômicos, identifica-se à terceira acepção apresentada, denominando-se "desenvolvimento econômico", para significar, grosso modo, o incremento da produção e a geração de dividendos. Esta sinonímia, ao adentrar na arena jurídico-político, contribuiu à difusão do ideário liberal, compreendendo-se que o crescimento almejado seria propiciado, inicialmente, pela livre iniciativa dos agentes privados, devendo o Estado

\footnotetext{
${ }^{4}$ As diversas especialidades ao segmentarem a realidade para analisa-la, ampliam a especificidade do conhecimento produzido sobre dado problema, mas perdem a percepção de como este problema se integra a diversos outros, objeto de estudos de outros campos do conhecimento. Assim, o conhecimento produzido se mostra parcial, na medida em que só consegue abordar aquela parcela da realidade de que se ocupa a especialidade que o produziu.

Por razões semelhantes, o conhecimento se mostra provisório. As potencialidades explicativas de qualquer conjunto teórico somente se mantem enquanto este não for substituído por outro que melhor aborde o fenômeno parcialmente estudado, conseguindo explicar elementos excluídos do conjunto original ou reconhecendo as interfaces do fenômeno com a realidade em que se insere etc. Isto é, o conhecimento é provisório, porquanto é provável sua substituição por outra explicação mais adequada do elemento estudado.
} 
abster-se de intervir nessa seara, para, a posteiori, fomentar suas atuações voltadas à proteção do mercado interno.

No entanto, esta concepção, ao se deparar com o incremento industrial, demonstrou-se insuficiente, pois não possibilitava a melhoria das condições de vida da população e, muitas vezes, era sua causa ou razão da sua piora. ${ }^{5} \mathrm{O}$ reconhecimento destas nuances importou na percepção de que: o homem condiciona e é condicionado pela sociedade, e que, neste processo, estabelecem-se diferenças entre os indivíduos, as quais exigem minorações ou correções voltadas a distribuir as benesses do crescimento econômico. A partir desta percepção, surgem direitos como o dos trabalhadores e a assistência aos que, por inúmeras razões, como a exclusão do processo produtivo, encontram-se vulneráveis. Assim, ao lado da expressão "desenvolvimento econômico", surge a ideia de "desenvolvimento social", muitas vezes considerada antagônica à primeira, mas que levou à ampliação dos campos de interesse das Ciências Econômicas, ao surgimento de outras áreas do conhecimento ocupadas de estudar temas relacionados à novel expressão e à nova geração/dimensão de direitos fundamentais. ${ }^{6}$

Todavia, a utilização dos recursos naturais para o processo produtivo, a ocupação antrópica do meio e o fomento ao consumo de bens e serviços para o "desenvolvimento social", levaram ao reconhecimento de que os homens impactam/degradam o ambiente e sofrem os efeitos destas ações.

\footnotetext{
5 "A revolução industrial apresenta ao mundo um novo tipo de homem até então desconhecido: o operário de fábrica. O aparecimento das máquinas produziu o desemprego em massa. Cada nova máquina introduzida na organização industrial jogava à rua centenas de milhares de empregados. O trabalho humano passa a ser negociado como mercadoria, sujeito à lei da oferta e da procura. O operário se vê compelido a aceitar salários ínfimos e a trabalhar quinze ou mais horas por dia para ganhar o mínimo necessário à sua subsistência. A mulher deixa o lar e procura no trabalho das fábricas um reforço ao salário do marido. As crianças não podem frequentar as escolas e são atiradas ao trabalho impróprio, prejudicial à sua formação física e moral, na luta pela subsistência que o pai não pode prover. E, assim, o liberalismo trazia mais no seu bojo, inconscientemente, a desintegração da família.

Quando colhido pela doença ou pela velhice quase sempre precoce, outra alternativa não restava ao operário senão estender a mão à caridade pública.

Por outro lado, o contraste era chocante: fortunas imensas se acumulavam nas mãos dos dirigentes do poder econômico; o luxo, a ostentação, a ânsia irrefreada de ganhar cada vez mais criaram o conflito entre as classes patronais e assalariadas.

Organizaram-se as grandes empresas, os trustes, os cartéis, os monopólios e todas as formas de abuso do poder econômico, acentuando-se cada vez mais o desequilíbrio social. E o Estado Liberal a tudo assiste de braços cruzados, limitando-se à polícia à ordem pública. É o Estado Polícia (L’État Gendarme). Indiferente ao drama doloroso da imensa maioria espoliada, deixa que o forte esmague o fraco, enquanto a igualdade se torna uma fiç̧ão e a liberdade uma utopia." (MALUF, Said. Teoria geral do Estado. 22. ed. revista atualizada pelo prof. Miguel Alfredo Malufe Neto. São Paulo: Saraiva, 1993. p. 130.)

${ }^{6}$ Essa taxonomia segue a doutrina de Paulo Bonavides, que relaciona os direitos fundamentais ao lema da Revolução Francesa, já que exprimiria todo o conteúdo possível daqueles. Tenha-se, porém, que a ideia de geração indica tão somente o surgimento ou desenvolvimento destes direitos, e não qualquer hierarquização entre eles, afinal, uma vez identificados como fundamentais, todos têm o mesmo status. Além disso, a interdependência e condicionamento mútuos implicam numa agregação de sentidos cujo efeito é, dentre outros, demonstrar a sua indivisibilidade e a dependência de formas diversas de manifestação estatal para sua tutela. (BONAVIDES, Paulo. Curso de direito constitucional. 4. ed. São Paulo: Malheiros, 1993. p. 474.)
} 
Assim, o "ambiente ecologicamente equilibrado" passa a demandar jurisdicionalização, mediante duas ordens de ideias acerca do desenvolvimento: uma de inspiração "biocêntrica" e, outra, de tendência "antropocêntrica".

A primeira, em sua versão exacerbada, proporia medidas que, na prática, tolheriam o homem de modificar o meio. Tal linha desconsidera que "a ação humana é, de per se, impactante" e que, "negar as possibilidades de mudança, implica na negação do homem, que, para sobreviver, precisa adaptar o meio às suas necessidades."7

A abordagem "antropocêntrica", também, em sua feição exacerbada, legitima a apropriação da natureza pela patrimonizalização dos bens ambientais, individualmente considerados. ${ }^{8}$ Nessa linha, o ambiente e seu equilíbrio são tomados em "uma visão naturalista", como "um espaço abstrato e sem conflitos" ${ }^{\prime \prime}$, porque identificado às pretensões de gerações futuras que, sempre futuras, jamais se tornam presentes - a questão ambiental se mostraria como uma política do porvir, o que nega a sua atualidade, e a premência dos problemas ambientais como se depreende dos debates envolvendo as mudanças climáticas. ${ }^{10}$

A primeira corrente, por desconsiderar o elemento antrópico, não foi, inicialmente tomada com seriedade, enquanto a segunda, ao se mostrar complacente à identificação entre "desenvolvimento" e "crescimento econômico", angariou maior número de adeptos e foi responsável por inúmeros avanços em termos técnicos, científicos e teóricos. Foi a partir desta abordagem que se desenvolveram novas áreas ou disciplinas, como a "Contabilidade Ambiental" e a "Economia de Recursos Renováveis", que, tratando os recursos naturais dentro da lógica da escassez - dentro do paradoxo econômico das necessidades ilimitadas face aos recursos escassos -, buscaram racionalizar a sua alocação, quantificar o patrimônio ambiental e mensurar os danos ambientais. Também é desta orientação que se originam os Estudos de Impacto Ambiental, as tentativas de se criarem medidas

\footnotetext{
${ }^{7}$ COSTA, Igor Sporch da. Para além das semelhanças: um ensaio sobre a autonomia e a simbiose entre o Direito Ambiental e o Direito Urbanístico. Revista dos tribunais, São Paulo, v. 946, p. 187-230, ago. 2014. p. 203.

${ }^{8}$ SILVA, José Robson da. Paradigma biocêntrico: do patrimônio privado ao patrimônio ambiental. Rio de Janeiro: Renovar, 2002. p. 60 e 222.

${ }^{9}$ FERNANDES, Edésio. Do código civil de 1916 ao estatuto da cidade: algumas notas sobre a trajetória do direito urbanístico no Brasil. In: MATTOS, Liana Portilho (Org.). Estatuto da cidade comentado: lei n. 10.257, de 10 de julho de 2001. Belo Horizonte: Mandamentos, 2002. p. 60.

${ }^{10}$ Esta exegese reducionista encontra suas bases numa leitura intencionalmente seletiva do caput do artigo 225 da Constituição, que, ao salientar a expressão "futuras gerações", olvida-se que o vocábulo "presentes" Ihe precede, acrescido de uma partícula que, longe de desconsiderá-lo ou negá-lo, designa uma adição. Logo, mais do que igualar as gerações, a construção do dispositivo traz, para o tempo atual, a emergência da questão, conforme se pode notar no texto citado: "Art. 225 - Todos têm direito ao meio ambiente ecologicamente equilibrado, bem de uso comum do povo e essencial à sadia qualidade de vida, impondo-se ao Poder Público e à coletividade o dever de defendê-lo e preservá-lo para as presentes e futuras gerações."
} 
compensatórias, reparadoras ou minorantes dos efeitos nocivos dos empreendimentos econômicos sobre o meio, bem como os cálculos de internalização das externalidades ambientais. ${ }^{11}$

Entretanto, ao se examinarem as alternativas pragmáticas fornecidas por essa segunda corrente, os adeptos da primeira identificaram-na como um meio de autorizar a devastação ambiental. Empreendimentos impactantes ao meio não eram impedidos, mas obedeciam à lógica de eficiência econômica - dentro do binômio custo/benefício - em que a degradação do meio apenas figurava como mais um componente dos custos, caso pudesse ser mensurada, o que, em regra se dava de forma subdimensionada. Nestas bases, um "desenvolvimento ecologicamente equilibrado", nominado "sustentável", apesar de querer indicar uma acomodação de significados - agregando as vertentes do "desenvolvimento econômico", do "social" e da "questão ambiental" - apenas ressaltava o antagonismo e uma lógica conflituosa que impossibilitava o seu manejo, por sempre exigir que se privilegiasse uma das três vertentes em detrimento das demais.

Na prática, tinha-se o privilégio da concepção de "desenvolvimento econômico", em prejuízo das demais. A ideia de "desenvolvimento social", apesar da carga normativa, presente em vários instrumentos jurídicos criados a partir dela, devido ao número de sujeitos, seria prejudicado por uma agenda reivindicatória que muitas vezes, mostrava-se fluida e pouco coesa, além da dificuldade em encontrar áreas permeáveis junto aos tomadores de decisões para pautar suas demandas.

O "desenvolvimento sustentável", por sua vez, conforme Ronaldo do Livramento Coutinho ${ }^{12}$, hodiernamente, tem se restringido ao plano retórico, como um padrão ético individual e de alguns grupos, sem eco nas atividades estatais e empresariais. Esta pouca ressonância decorreria do processo de construção da ideia, marcado por pouca objetividade que, se por um lado, possibilitou a sua ampla aceitação, por outro, prejudicou o grau de cogência imprescindível à apreensão de suas balizas semânticas e à aferição dos comportamentos conformes à figura. ${ }^{13}$

Não obstante estas dificuldades, a ideia de sustentabilidade que, paulatinamente vai se objetivando, fruto de todo o processo acima apresentado, parece fundar-se num meio termo entre "antropocentrismo" e "biocentrismo". Alguns denominarão esta terceira via de "antropocentrismo

\footnotetext{
${ }^{11}$ COASE, Ronald H. O problema do custo social. In: SALAMA, Bruno Meyerhof (Org.). Direito e economia: textos escolhidos. São Paulo: Saraiva, 2010. p. 59-112.

${ }^{12}$ COUTINHO, Ronaldo do Livramento. Anotações críticas sobre o discurso da sustentabilidade. In: COUTINHO, Ronaldo do Livramento; AHMED, Flávio (Org.). Cidade, direito e meio ambiente: perspectivas críticas. Rio de Janeiro: Lúmen Juris, 2011. p. 1-12.

${ }^{13}$ Não se pense, porém, que isto significa que a tutela ambiental ocuparia, sempre, o último posto numa gradação entre as figuras trabalhadas. Em pesquisa empreendida pela professora Ângela Moulin Penalva Santos, acerca da descentralização, participação e controle externo sobre os municípios de médio porte fluminenses, percebeu-se que as poucas "intervenções" do Ministério Público se centravam na seara ambiental, não merecendo os temas relativos à política urbana, educação e saúde a mesma atenção. (SANTOS, Ângela Moulin Penalva. Descentralização, participação e controle externo sobre os governos municipais no Brasil. Geo UERJ, Rio de Janeiro, a. 11, v. 2, n. 19, p. 17-43, 10 semestre de 2009. p. 29, 37-38 e 40-41).
} 
alargado" por retirar "a ótica produtivista/patrimonialista liberal", e privilegiar o homem, "sua dignidade e a tutela ambiental", identificando-o "como parte do meio, por modificá-lo e por dotá-lo de significado"14, cuidando, assim de uma "repersonalização do Direito Ambiental":

Contra este desequilíbrio insurge-se um direito crítico que se afirma sobre outros paradigmas, nomeadamente, a dignidade humana. Nesta reação epistemológica concentra-se a repersonalização do direito. Uma repersonalização que, no âmbito do direito patrimonial, revela a abertura do sistema para um patrimônio mínimo como um direito subjetivo daqueles que vivem no sistema capitalista. [...]

A idéia de uma repersonalização do direito patrimonial representa, portando uma superação do antropocentrismo de cores clássicas, marcadamente individualistas e competitivas que cedem lugar para a complexidade e solidariedade nas relações humanas. Esta complexidade e solidariedade representam o reconhecimento de que as relações fundadas exclusivamente no princípio da autonomia da vontade estão separadas. O sistema, a partir destas premissas afirma e instrumentaliza preocupações com a sorte de todos os seres humanos, nomeadamente, daqueles que historicamente foram postos à margem do sistema. ${ }^{15}$

Afasta-se, assim, tanto a lógica harmônica, de pronto fornecida, quanto a conflitual, impeditiva do processo de tomada de decisões, para se reconhecer que "desenvolvimento econômico", "desenvolvimento social" e "desenvolvimento sustentável" estão em tensão. Isto é, a oposição não se mostra, de pronto insolúvel, e a harmonização não é um dado, mas um construído caso a caso o que viabiliza a produção de alternativas de mais amplo espectro por problematizar os elementos envolvidos e importar na definição, in concreto, de comportamentos sustentavelmente adequados - seja no tocante à atividade legiferante, seja na expedição de um ato administrativo ou na solução de litígios.

\footnotetext{
${ }^{14}$ COSTA, Igor Sporch da. Op, cit., p. 203-205.

${ }^{15}$ Nesta seara, temas como a miséria ganham importância, por se reconhecer nela uma das causas do processo de segregação e degradação ambiental, que fazem com que o acesso e a utilização dos bens ambientais representam, às populações carentes, condições de sobrevivência. (SILVA, José Robson da. Op. cit., p. 203-204 e 42, 54-58, 96-99, 242, 262-267.)

Esta citação, do professor José Robson da Silva, consta das páginas 205-206, do já mencionado artigo "Para além das semelhanças: um ensaio sobre a autonomia e a simbiose entre o Direito Ambiental e o Direito Urbanístico", da lavra de um dos autores do presente ensaio, publicado pela Revista dos tribunais, no seu volume 946 - ago. 2014. Entretanto, por um equívoco de formatação da citada revista, não se abriram aspas no texto, indicando se tratar de uma citação direta, embora no seu final seja indicada a autoria do trecho na nota de rodapé número 38.

O mesmo problema ocorreu em mais duas ocasiões do mencionado ensaio: à página 202, no parágrafo iniciado pela expressão "Como tenho afirmado...", até "... relação de propriedade.", que, como indicado na nota 32, foi retirado de texto de autoria do professor Edésio Fernandes; e às páginas 211-212, em que o parágrafo iniciado por "Essa especificidade...", até o próximo, encerrado por "... cidades brasileiras.", que como indicado na nota 51, pertence à professora Juliana de Souza Reis Vieira.

De qualquer forma, aproveita-se a oportunidade para desfazer o equivoco e pedir sinceras desculpas aos autores e leitores tanto daquele, quanto deste trabalho.
} 
Esta noção ampliada de sustentabilidade recupera de suas origens antropocêntricas a lógica da eficiência econômica, de forma a considerar não somente os resultados/benefícios, mas, outrossim, a contabilização dos custos envolvidos ${ }^{16}$ e a sua internalização pelo produtor, como se faz perceber, por exemplo, pela imposição de mecanismos de logística reversa. No entanto, reconhecesse-se que a apuração dos custos e benefícios possuem uma dimensão mensurável e outra de difícil quantificação por envolver a dimensão pessoal dos beneficiários e atingidos pelas medidas, o que põe em discussão outros conceitos/binômios, como a efetividade ${ }^{17}$, ou a relação entre estes e aqueles. ${ }^{18}$

A sustentabilidade exige, pois, o delineamento das diversas políticas públicas, reconhecendo seus pontos de contato, suas interseções e a as formas como umas impactam nos objetivos das outras. Isto, obviamente, complexifica o processo de tomada de decisões, mas, também, aclara a interdependência e a margem de manejo destas variáveis, o que possibilita que tais decisões possuam maior probabilidade de produção de efeitos adequados:

Esta tomada de posição põe em causa as relações sociais e econômicas entre os homens e destes com o meio - pautadas pela hipossuficiência da mão-de-obra, pelos impactos na estruturação social, e pelo processo de produção de mercadorias baseado no consumo dos bens naturais, que perpassa a sua apropriação privada e a sua degradação, com a conseqüente geração de resíduos a serem descartados no meio. Assim, é que se faz necessária uma análise crítica sobre todo o quadro, e que considere os reais efeitos do uso de "tecnologias limpas" e outras técnicas, como "os processos de educação ambiental, ou mesmo a incorporação de indicadores sócio-ambientais no cálculo e na especificação de alguns produtos e processos produtivos nas transações comerciais"19

Longe de se desprestigiar a técnica e o papel dos avanços tecnológicos na construção de soluções aos problemas ambientais, quer-se, aqui, demonstrar a necessidade de se aliar tal vertente às questões sociais, pois não são divorciáveis - o que, aliás, reforça as críticas tecidas à desumanização do Direito Ambiental. Dotar o desenvolvimento sustentável de densidade normativa exige

\footnotetext{
${ }^{16}$ Buscando-se mensurar nestes custos os impactos ambientais e sociais com fulcro nos novos desenvolvimentos técnico-científicos.

17 A efetividade implica numa mensuração de causa/efeito, em que a ação se mostra como geratriz de uma mudança social em consonância/dissonância ao fim almejado. (COSTA, Igor Sporch da. Igualdade na diferença e tolerância. Viçosa: Editora UFV, 2007. p. 181-186.)

${ }^{18}$ Como, por exemplo, a tentativa de medir o custo/efetividade, em que se parte dos valores dispendidos face aos benefícios atingidos, escalonados em graus de modificação social desejados.

19 Embora, os "avanços obtidos com a introdução de tecnologias de produção menos absorventes de recursos naturais e com mecanismos de controle de poluentes, bem como apesar dos investimentos em gestão ambiental", estudos indicam que os níveis de degradação ambiental têm aumentado, e tais avanços "vão desde a referência às tecnologias 'sujas' até a crítica ao consumo exacerbado, face ao esgotamento dos recursos naturais e ao aumento dos resíduos" (COUTINHO, Ronaldo do Livramento. Anotações..., p. 6.)
} 
operacionalizá-lo para viabilizar sua capacidade de regulação de comportamentos, o que exige considerar tais imbricações $[\ldots]^{20}$

Estes elementos demonstram que as lógicas tradicionais aplicadas às políticas públicas pautadas na perquirição do custo de implantação/manutenção, face aos resultados objetivamente quantificáveis - embora importantes, não se mostram suficientes pois são reducionistas. A tais expedientes devem-se somar as especificidades ínsitas a cada fase, tipologia ou parte dos componentes da aludida ação pública, aplicando-se tal conjugação para demonstrar a razão de se adotar dado caminho face a todas as alternativas técnicas disponíveis, e não como mera formalidade destinada a corroborar decisões previamente definidas. Ao conjunto se agregam os elementos sociais - concernentes às interferências nas mais variadas nuances da vida humana e coletiva, não restritos aos aspectos da atração ou expulsão populacional - e ambientais - avaliando conjuntamente os impactos nos macro e micro bens ambientais. Logo, os elementos ambientais e sociais, ao abraçarem parte das contribuições fornecidas pela corrente biocêntrica, não se mostrarão meros componentes do cálculo de pretensões reparatórias, mas se apresentarão como mecanismos aptos a viabilizar outras opções ou, até mesmo, inviabilizar ações, na medida em que seus argumentos, tomados em pé de igualdade com os demais, apresentarem-se mais adequados ou proporcionai. ${ }^{21}$

Inverte-se, assim, a lógica: não se toma a decisão para, posteriormente, buscar explica-la pela sustentabilidade, mas é esta que - ao fornecer as alternativas, os impactos esperados, e a forma de quantificá-los e minorá-los - indicará as decisões passíveis de serem tomadas. Isto é, a sustentabilidade torna-se um dos motivos pelos quais se tomou a decisão.

Fixada a noção de sustentabilidade nestes termos e reconhecendo as suas possibilidades de orientar o processo decisório, tem-se alguns elementos para se analisar a política energética brasileira no que toca aos tipos que compõem sua matriz, apontando-se os seus processos de geração e os riscos envolvidos, para, em seguida, operar-se a sua conjugação com alguns dos elementos, aqui apresentados. Este é o objeto da próxima seção.

\section{NOTAS SOBRE A POLÍTICA ENERGÉTICA BRASILEIRA}

Questões envolvendo o tema "energia" ocupam papel central nas preocupações do homem, pois, a sua adaptação ao meio demanda o consumo energético - seja a força motora de seus braços, de animais, da combustão de fontes fósseis, a eletricidade, ou as tecnologias envolvendo átomos. Diante dessa constatação, a produção/consumo de energia adentra a agenda governamental como

\footnotetext{
${ }^{20}$ COSTA, Igor Sporch da. Op, cit., p. 222-223.

${ }^{21}$ Isto é, às vezes, serão os elementos social ou ambiental considerados estático para que os elementos técnico ou econômico variem, enquanto, noutras situações aqueles variarão em razão dos segundos - o que se determinará conforme as especificidades do caso concreto e a interdependência entre as medidas.
} 
tema prioritário de "desenvolvimento econômico", constituindo-se as medidas concernentes à matéria uma política pública.

Como toda política pública, a energética se marca por um conjunto de ações programadas e planejadas no âmbito estatal22, que, partindo do diagnóstico de elementos relativos à produção e ao consumo de energia - como, elementos físicos, financeiros, ambientais e sociais - estabelece um prognóstico desejado - uma situação a ser implementada relativa à demanda de energia para a produção de bens e serviços, consumo doméstico e as mais variadas atividades humanas - bem como um a ser afastado - concernente, por exemplo, na carência de oferta ou ao alto custo de produção/distribuição, a ser repassado aos consumidores. Para realizar o primeiro prognóstico - e, consequentemente, evitar o segundo - estabelecem-se programas e ações voltadas a atingi-lo, numa lógica racional entre a situação fática constatada e aquela que se almeja.

Tais programas e ações concretizam, assim, as diretrizes e metas fixadas nos planos que contêm a aludida política pública - no caso brasileiro, os Planos Decenais de Expansão de Energia - as quais serão implantadas em curto, médio ou longo prazos, consoante a alocação/realização de cada ação, ou conjunto de ações concretas. Ademais, cada uma dessas estruturas deve considerar as futuras demandas energéticas e conter cláusulas de modificação/adequação a mudanças conjunturais, cujo grau de antecipação e possibilidade de controle estatal se apresenta variável.

Além dos textos normativos acima mencionados ${ }^{23}$, tem-se a produção de peças técnicas que, incorporadas ou não aos primeiros documentos, diagnosticam a situação brasileira e permitem esquadrinhar a sua evolução a partir da comparação entre documentos produzidos em períodos distintos. Este é o caso, por exemplo, da Matriz Energética, contida no Balanço Energético Anual BEN.

\footnotetext{
${ }^{22}$ Apesar de definida no âmbito estatal, isso não significa que ela se restrinja às ações do Estado. Ao contrário, a sua execução pode se efetivar por uma miríade de formas jurídicas, como leis, atos unilaterais, processos, além da transferência, para o setor privado, por meio de contratos de gestão ou parecerias, por exemplo. LEAL, Rogério Gesta. Gestão pública compartida e organizações sociais: um novo paradigma à administração pública. In:__ ARAUJO, Luiz Ernani Bonesso de (Orgs.). Direitos sociais \& políticas públicas: desafios contemporâneos. Santa Cruz do Sul: EDUNISC, 2001. p. 35-110.

${ }^{23}$ Os textos normativos em comento constituem-se em planos, programas, ações, os quais possuem, na hipótese, natureza jurídica de atos administrativos, e, portanto, infralegais, embora se possa conjeturar que uma lei contenha o aludido plano decenal.
} 


\section{A matriz energética brasileira}

A Matriz Energética nacional é a representação gráfica de tudo o que, em um ano, foi, gerado ${ }^{24}$ pelas diversas fontes energéticas e do que foi consumido por todos setores da sociedade, como se vê pela figura abaixo, que contém a Matriz Brasileira, ano-base 2013:

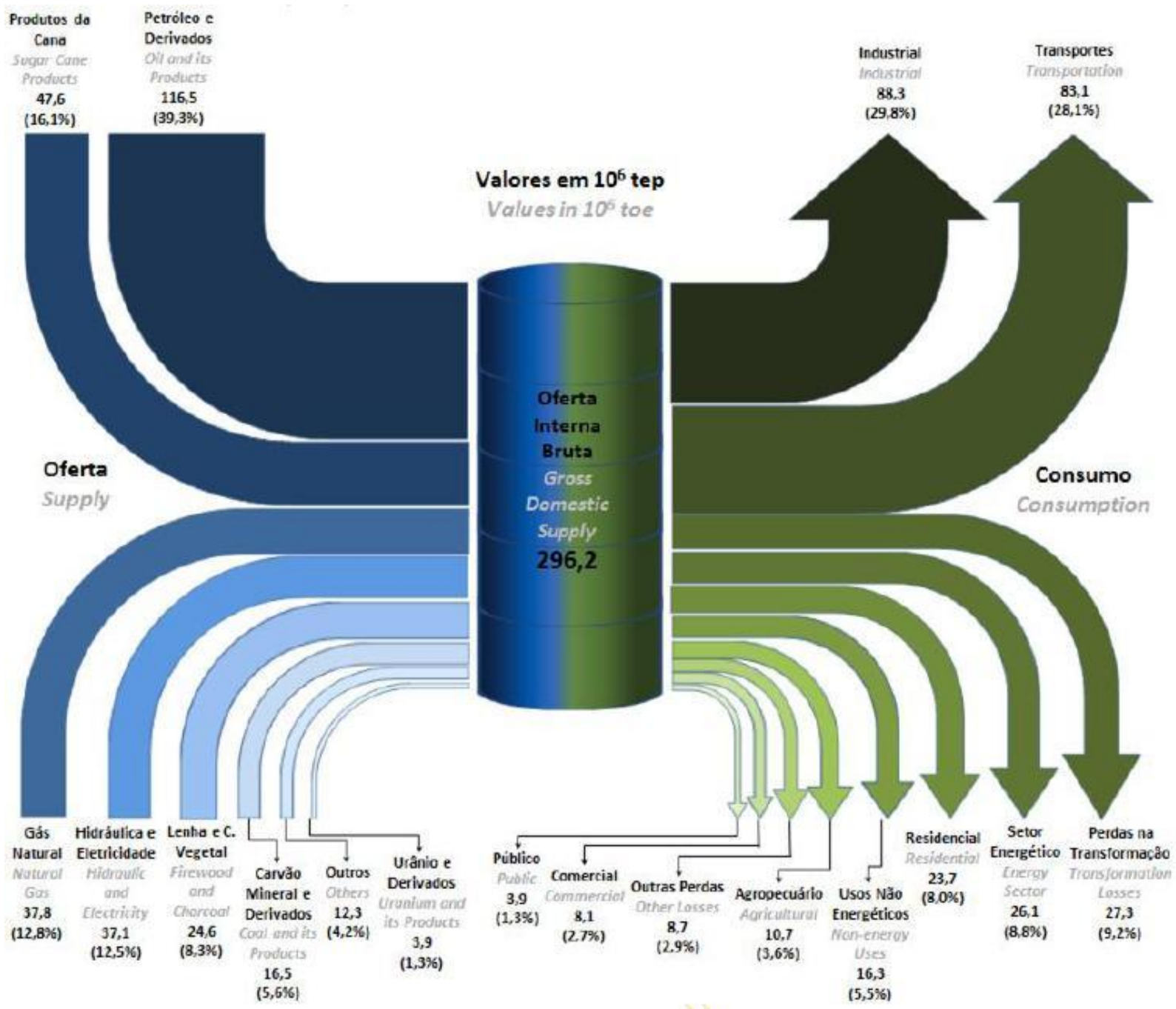

24 O vocábulo "gerado" e suas variações, neste ensaio, quando se referir à energia "gerada", compreende tanto o que foi produzido nacionalmente, quanto a energia importada. 
Como se depreende da Figura 1, atualmente, a Matriz Energética Brasileira ${ }^{25}$ é, em sua maior parte $(80,7 \%)$, originada pelas seguintes fontes: petróleo e seus derivados (39,3\%); produtos provenientes da cana de açúcar (16,1\%); gás natural (12,8\%); produção de energia hidrelétrica (12,5\%). Ainda, de acordo com a citada Matriz, os maiores consumidores são os setores industrial $(29,8 \%)$ e de transportes $(28,1 \%)$, responsáveis por consumirem mais da metade do total de energia nacional $(57,9 \%)$, o que se explicaria pelo consumo para fabricação e transformação de matériasprimas em bens manufaturados, no primeiro caso, e o gasto energético em combustíveis, no segundo.

Considerando-se somente o fluxo de energia elétrica - os quantitativos gerados e consumidos deste tipo de energia - no Ano-base 2013, tem-se a Matriz Energética Elétrica Brasileira. Esta, como aquela da qual se origina, é a representação anual de tudo o que é, de um lado, gerado pelas fontes existentes e, lado outro, do gasto total, também dividido por setores, nos termos expostos na Figura 2:

25 EMPRESA DE PESQUISA ENERGÉTICA (EPE). Balanço energético nacional 2014: ano base 2013. Rio de Janeiro: EPE, 2013. p. 26. 
Figura 2: Matriz energética elétrica brasileira - ano base 2013.
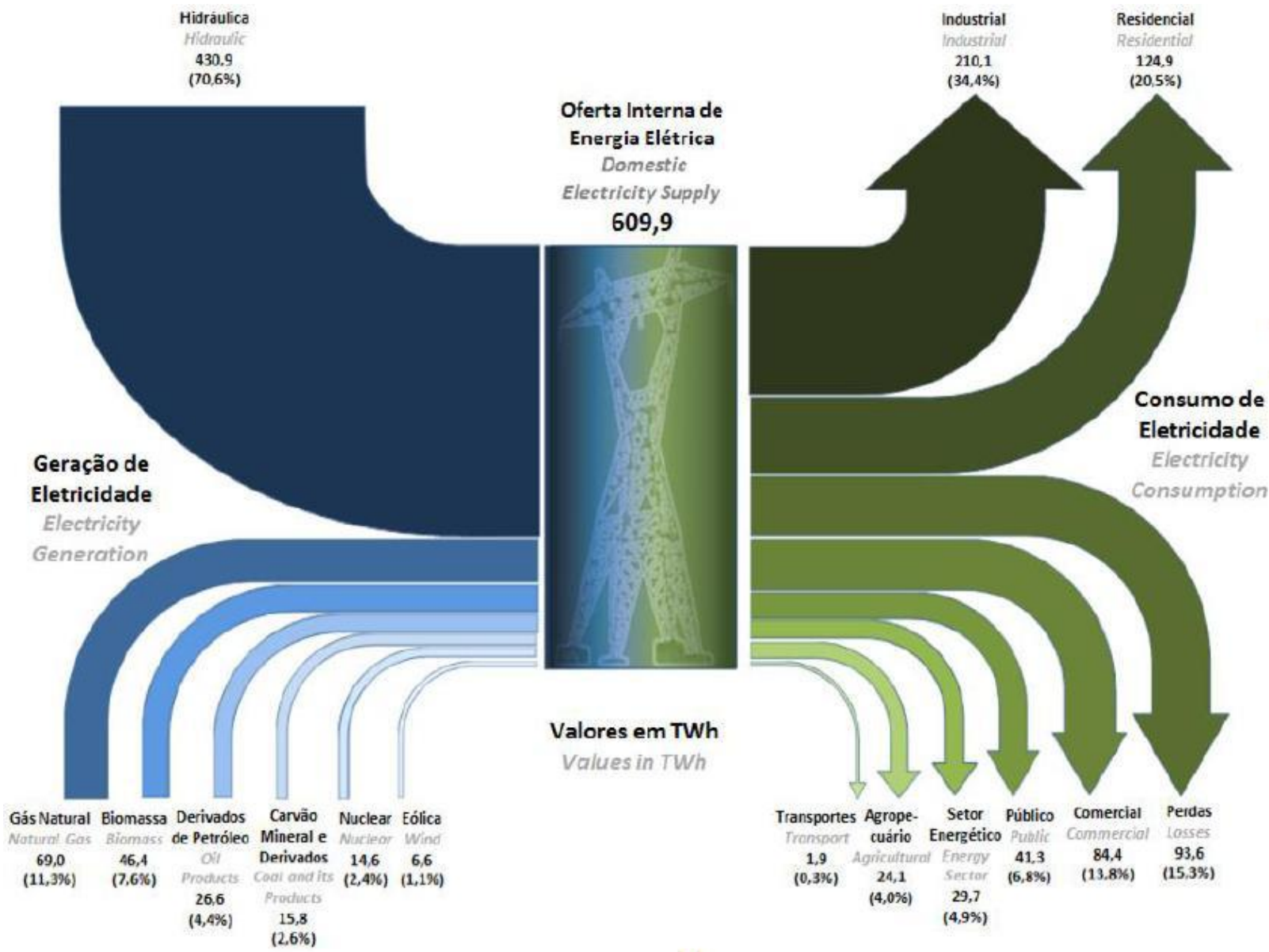

Fonte: EMPRESA DE PESQUISA ENERGÉTICA (EPE). Balanço energético nacional 2014: ano base 2013. Rio de Janeiro: EPE, 2013. p. 35.

Ministério de Minas e Energia ${ }^{26}$, uma geração no montante de 609,9 TWh $^{27}$, proveniente, em sua maior parte, das hidrelétricas $(70,6 \%)$, seguida, das fontes de gás natural $(11,3 \%)$ e de biomassa $(7,6 \%)$, figurando outras fontes com menor representatividade, como os derivados de petróleo $(4,4 \%)$, carvão mineral e derivados (2,6\%), nuclear $(2,4 \%)$ e eólica (1,1\%). O consumo da energia gerada deuse, primordialmente, pelos setores industrial $(34,4 \%)$ - não incluído o setor energético que, no ano base em análise, consumiu $4,9 \%$ - e residencial $(20,5 \%)^{28}$, representando a soma dos dois principais

\footnotetext{
${ }^{26}$ Ibid., p. 35

271 TWh equivale a $1 \times 10^{12} \mathrm{~W}$, ou seja, 1.000.000.000.000W; sendo o Watt uma medida de potência de energia, equivalente a $1 \mathrm{~J} / \mathrm{s}$ - leia-se: 1 Joule por segundo. Já o Joule é uma unidade de medida utilizada para a energia mecânica, em que: $1 \mathrm{~J}=1 \mathrm{~kg} \times \mathrm{m}^{2} / \mathrm{s}^{2}$ - leia-se: 1 Joule é igual a 1 kilograma força multiplicado por 1 metro ao quadrado, dividido por 1 segundo ao quadrado.

28 De acordo com a Matriz Energética Nacional - Ano-base 2013 - o segundo setor consumidor de energia foi o de transportes. Entretanto, tal setor, na Matriz Energética Elétrica Brasileira do mesmo ano, figura como o de menor consumo (0,3\%). Esta discrepância decorre do fato de que o setor se constitui, em sua grande maioria,
} 
setores consumidores - industrial e residencial - o montante de $54,9 \%$ do consumo total nacional; ao passo que o consumo do setor comercial correspondeu a $13,8 \%$ do consumo total, inferior às perdas de energia ${ }^{29}$, apuradas no quantum de $15,3 \%$ do total gasto.

Todavia, a representação gráfica, contida nas matrizes energéticas, possibilita outro importante elemento para o planejamento da política energética nacional, a comparação/evolução da geração e do consumo nacional. Neste exercício, tome-se a Matriz Energética Elétrica brasileira, Anobase de 2012, constante da Figura 3:

por transporte rodoviário - inclusive, para o escoamento da produção industrial, mediante o emprego de veículos pesados - que, neste caso, não utilizam energia elétrica para locomoção, mas combustíveis, em sua maioria, derivados do petróleo, como o diesel e a gasolina.

${ }^{29}$ Para que a energia elétrica gerada chegue ao consumidor final, para utilização, são necessárias várias etapas de transformação e distribuição, quais sejam: inicialmente, transforma-se a energia de baixa para alta tensão, para, então, seguir da unidade produtora, à distribuição; a distribuição é feita por linhas de transmissão, e, quanto maior a distância da unidade produtora à unidade de consumo - consumidor final - maiores são os gastos energéticos do sistema; antes da energia ser fornecida ao consumidor, novamente se opera a sua transformação de alta para baixa tensão, portanto em sentido inverso à primeira operação realizada.

Assim, não se confundem as perdas de energia com as demandas de energia pelo setor gerador. Neste caso trata-se de consumo de energia para a geração, ao passo que as perdas ocorrem entre as fases de produção, transformação e distribuição, constituindo-se tais minorações em algo ínsito ao processo, o que, porém, não afasta a possibilidade de se implementarem medidas voltadas à sua redução - pois, como se nota da Matriz Energética Elétrica, ora analisada, as perdas representaram, no Ano-base de 2013, 15,3\% do total gasto. 
Figura 3: Matriz energética elétrica brasileira - ano base 2012.
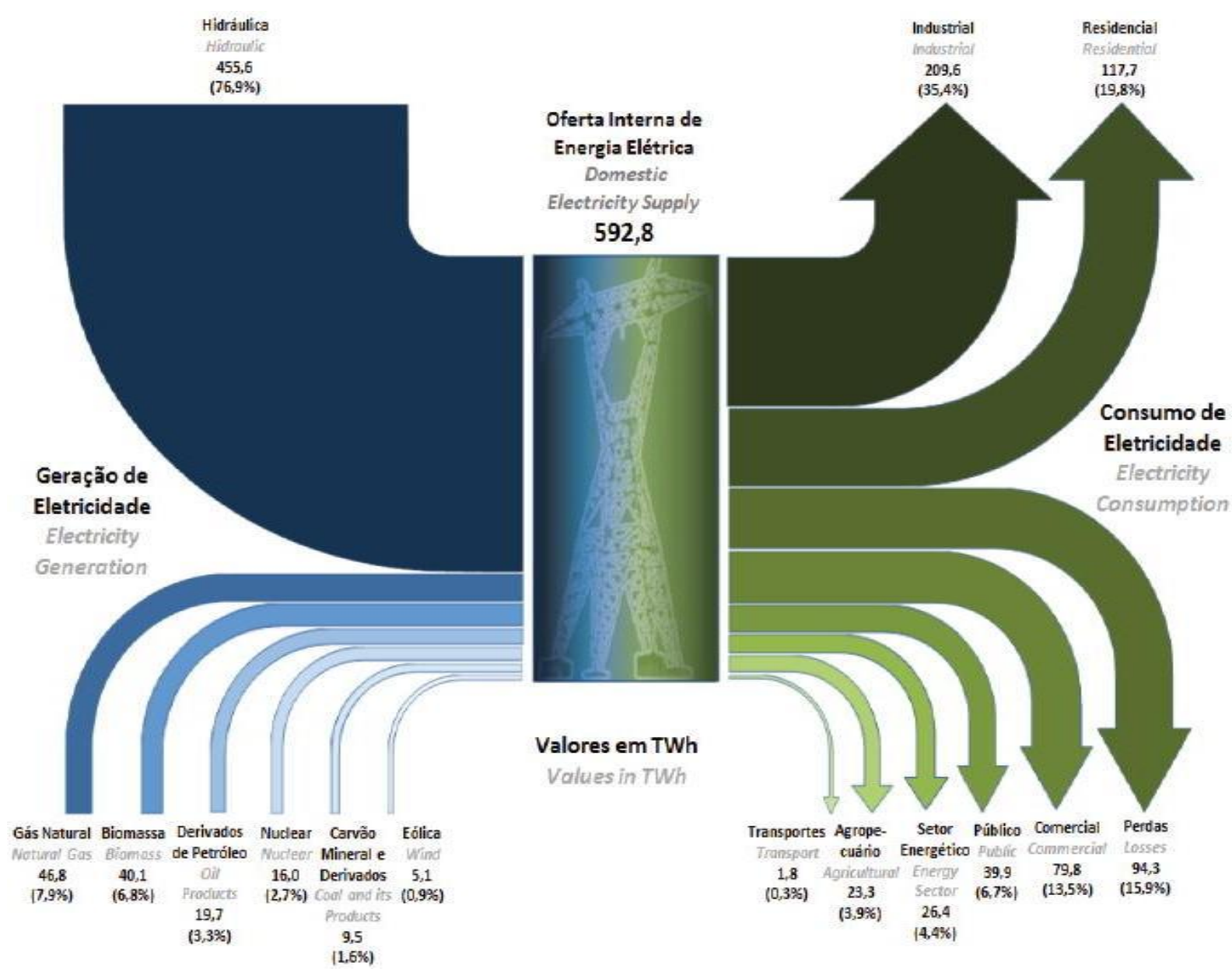

Fonte: EMPRESA DE PESQUISA ENERGÉTICA (EPE). Balanço energético nacional 2013: Ano base 2012. Rio de Janeiro: EPE, 2013, p. 38. 
Tabela 1: Comparativo entre as Matrizes Energéticas Elétrica do Brasil Anos-Base 2012 e 2013

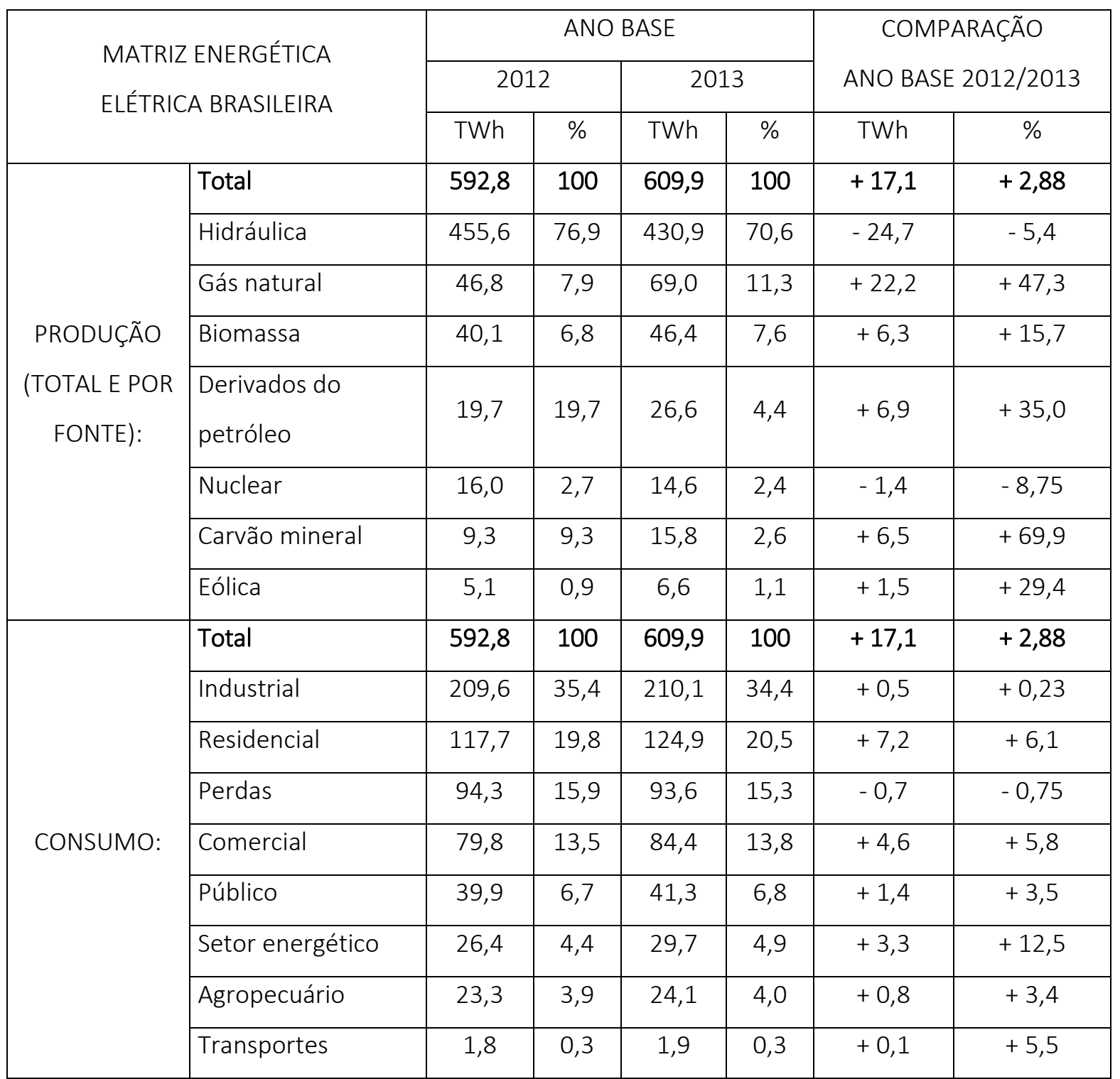

Fonte: Tabela elaborada pelos autores, com dados extraídos das Matrizes Energéticas Elétricas brasileiras dos Anos-base 2012 e 2013.

A comparação entre as aludidas Matrizes Energéticas Elétricas, Anos-base 2013 e 2012 Figuras 2 e 3 e Tabela 1-possibilita constatar, no tocante ao consumo, que: o setor industrial manteve o gasto de energia elétrica praticamente inalterado, com um aumento de 0,23\% (0,5 TWh); houve uma redução nas perdas de energia elétrica no importe de 0,75\% (0,7 TWh), embora o gasto de energia pelo setor elétrico tenha aumentado em 12,5\% (3,3 TWh). Nos demais setores, houve um aumento do consumo no importe de: 5,5\% (0,1 TWh), no setor de transportes; 3,4\% (0,8 TWh), no setor agropecuário; 3,5\% (1,4 TWh), no setor público; 5,8\% (4,6 TWh), no setor comercial; e, no setor 
residencial operou-se uma majoração de 6,1\% (7,2 TWh), o que representa o maior aumento de consumo absoluto do período.

Esta mesma comparação, focada no âmbito da geração, atesta um aumento na oferta total no importe de 2,88\% (17,1 TWh). Porém, quando se comparam as fontes de energia, nota-se uma redução no fornecimento de energia hídrica, no montante de 5,4\% (24,7 TWh), com um consequente aumento da participação das outras fontes, nos seguintes quantitativos: carvão mineral - 69,9\% (6,5 TWh); gás natural - 47,4\% (22,2 TWh); derivados do petróleo - 35,0\% (6,9 TWh); eólica - 29,4\% (1,5 TWh); e biomassa - 15,7\% (6,3 TWh).

Estão presentes, assim, os dados necessários à discussão sobre as diversas fontes que compõem a Matriz Energética Elétrica nacional. Sobre isso versará a próxima subseção.

\section{Tipos de produção de energia}

Para que ocorra a produção de energia elétrica é necessário que qualquer fonte com potencial de produção energético - água, vento, sol, petróleo etc - passe por um processo que consiste, em linhas gerais, na conversão da energia potencial do material. Este movimenta uma turbina com rotação mecânica - gerador mecânico - que é acoplada a um gerador elétrico, que, por sua vez, transforma a energia mecânica da turbina em eletricidade. ${ }^{30}$

Percebe-se, assim, que múltiplas são as fontes dotadas de capacidade geradora de energia, podendo-se classificá-las com base em inúmeros critérios, sendo, talvez, o mais conhecido deles, a possibilidade de sua renovação. Com base neste elemento taxonômico, as fontes de energia podem ser classificadas em renováveis e não-renováveis.

As fontes não-renováveis são, sobretudo, as que utilizam recursos extraídos do meio natural, mas que demoram até bilhões de anos para que a natureza possa fazer a reposição do material extraído, como é o caso dos combustíveis fósseis. Por sua vez, as fontes de energia renováveis são aquelas encontradas, atualmente, em abundância na natureza, cuja reposição seja rápida e frequente.

Como exemplo de fontes renováveis tem-se a energia hidráulica, proveniente de água doce, produzida numa usina hidrelétrica. Após passar pelas turbinas, a água continua seu caminho pelo leito do rio, podendo ser empregada em outras finalidades, como o abastecimento de água, até desaguarem em outros rios ou no oceano. Durante o percurso, parte dessa massa de água evapora e, por meio do ciclo das chuvas, volta aos rios - balanço hídrico - e, consequentemente, às barragens, dando, assim, continuidade ao ciclo.

\footnotetext{
${ }^{30}$ Como se verá mais à frente, ainda nesta subseção, o processo de produção a partir da energia solar, segue os mesmos princípios, porém utilizando outra tecnologia.
} 
Outra fonte renovável é a eólica, que, sem alterar as características físico-químicas do ar, utiliza as correntes de vento para rotacionar as turbinas e, assim, produzir eletricidade. No caso, a renovação decorre do ciclo interligado e incessante dos ventos pelo planeta.

Além das fontes de energia renováveis citadas, existem: a solar, a maremotriz ${ }^{31}$, a geotérmica ${ }^{32}$, a biomassa, o biogás e o biodiesel. ${ }^{33}$ Destas, o Brasil, somente implantou unidades produtoras de energia elétrica tendo por fontes a biomassa e a radiação do sol.

Uma segunda forma de classificar as fontes de energia é a sua capacidade de poluir ou liberar compostos poluentes. Assim, uma fonte é considerada limpa se, durante a fase de produção de energia, não se liberam resíduos tóxicos ou que degradem o ambiente, em termos de compostos à

\footnotetext{
${ }^{31}$ A energia maremotriz utiliza a força das águas oceânicas. A produção de energia fundada nesta fonte se subdivide em dois tipos: energia cinética das correntes devido às marés e, energia potencial pela diferença de altura entre as marés alta e baixa.

Para a produção do primeiro tipo, é necessária a instalação, em alto mar, de torres dotadas de pás, interligadas com turbinas mecânicas acopladas a um gerador elétrico. Estas pás ficam submersas e a corrente marítima, ao passar por elas, movimentam-nas, gerando energia.

A segunda espécie exige a construção de uma barragem dentro do mar e a instalação de moinhos na área da barragem que fica submersa. Quando a maré alta ultrapassar a barragem, a água será represada e, na maré baixa, movimentará os moinhos, produzindo energia mecânica a ser transformada em eletricidade.

No Brasil, somente os estados do Maranhão, Pará e Amapá apresentam condições geográficas favoráveis à produção de energia maremotriz, cuja principal vantagem, além de ser renovável e constante, é se constituir em energia livre da produção de gases poluentes. No entanto, os altos custos de instalação, implantação e conservação apresentam-se como entraves financeiros. Além destes, devem ser mensurados, outrossim, os impactos socioeconômicos e ambientais, decorrentes do empreendimento, como os prejuízos às rotas de cardumes, e outros animais, extraídos por empresas pesqueiras e/ou populações tradicionais. (MINISTÉRIO DO MEIO AMBIENTE. Energia maremotriz. Disponível em: <http://www.mma.gov.br/clima/energia/ energiasrenovaveis/energia-maremotriz>. Acesso em: 14 jul. 2014).

32 A energia geotérmica consiste em aproveitar as altas temperaturas do interior da Terra para sua transformação em eletricidade, mediante o aquecimento de água e sua transformação em vapor - ou utilizando os vapores expelidos naturalmente, como no caso dos gêiseres - que movimentaria uma turbina mecânica com os geradores elétricos acoplados. No Brasil não existem condições naturais para o emprego destas fontes, o que impossibilita a sua inserção na matriz nacional.

${ }^{33}$ Embora exista no Brasil para aplicação no setor de transportes, o emprego do biodiesel na geração de eletricidade não se mostra muito difundido. De qualquer forma, tem-se que sob esta denominação está o combustível produzido a partir de diversas fontes vegetais, misturado ao etanol ou metanol, utilizado no setor de transportes. O seu processo de produção consiste na extração do óleo vegetal e na sua transformação em combustível pelo refinamento do óleo e adição de álcool.

As principais vantagens desta fonte são que: a emissão de $\mathrm{CO}_{2}$ é menor que a proveniente de derivados do petróleo, pois, considera-se que o $\mathrm{CO}_{2}$ emitido é consumido na fase de crescimento das plantações, o que explicaria a utilização da expressão "combustível renovável" para identifica-lo; haveria, ainda, a geração de emprego e renda em zonas rurais; a redução da dependência do petróleo como utilização em combustível; e a geração de glicerina como subproduto do processo, a qual poderia ser reaproveitada, com geração de ativos financeiros, pelas indústrias alimentícia, cosmética e farmacêutica.

No entanto, estes pontos favoráveis não são isentos de críticas: é discutível a ideia de que o $\mathrm{CO}_{2}$ emitido durante a utilização do combustível será consumido durante o período de crescimento das fontes vegetais; ademais, as diversas críticas incidentes sobre as grandes plantações de soja também se aplicariam à hipótese, concernentes à maior utilização da terra para plantação de fontes vegetais destinadas à indústria energética, em detrimento da produção alimentícia, com a consequente expulsão do contingente humano para outras regiões e agravamento da crise no campo pelo aumento da concentração de terras.
} 
base de $\mathrm{CO}$ (monóxido de carbono) e $\mathrm{CO}_{2}$ (dióxido de carbono). Esta dispersão é característica de processos que demandem queima do combustível - fonte energética - alterando suas propriedades físico-químicas, e acarretando a liberação de compostos, com alta capacidade poluente, causando diversos impactos ambientais de difícil contenção. Inserem-se neste grupo o gás natural, os derivados de petróleo e o carvão mineral.

Outra fonte energética considerada não-renovável e não-limpa é a energia nuclear. Na sua produção, altera-se o material - no caso brasileiro, o urânio - na sua constituição atômica, o que libera calor que, ao aquecer a água, transforma-a em vapor que movimenta uma turbina mecânica, acoplada a um gerador elétrico. A energia nuclear é considerada não-renovável, devido ao tempo para formação natural da fonte/mineral empregado, e, não-limpa, porque, embora não produza monóxido ou dióxido de carbono, gera lixo tóxico radioativo, que deve ser depositado em locais com isolamento apropriado - em regra, chumbo - e, constantemente, monitorados.

As vantagens deste sistema são: no caso brasileiro, o custo com a aquisição do componente, já que é produzido nacionalmente, embora, para atender a demanda interna, realize-se importação do material; a eficiência da fonte, pois com pouca quantidade do material, produz-se grande montante de energia; não gera gases causadores do efeito estufa, apesar de os resíduos produzidos serem tão ou mais perigosos que aqueles. Tais dados têm levado o Estado brasileiro a propugnar a construção de outra usina nuclear, não obstante os riscos e desvantagens envolvidos, que, além da produção de lixo radioativo e do constante monitoramento dos aterros nucleares, inclui: a alteração do ecossistema, devido à eliminação de águas com elevadas temperaturas; o risco de acidente nuclear; a possibilidade de utilização para fins bélicos - o que já se considerou ponto favorável ao desenvolvimento deste sistema; e os altos custos de investimentos iniciais durante a fase de implantação e de operação. ${ }^{34}$

As fontes térmicas de energia, ou termelétricas, também são consideradas fontes nãorenováveis e não-limpas. Elas, geralmente, usam combustíveis fósseis para produção de energia, como o petróleo e seus derivados, gás natural e carvão mineral, em que tais materiais são queimados e a fumaça liberada movimenta a turbina mecânica, que é acoplada ao gerador elétrico. De acordo com o Ministério de Minas e Energia ${ }^{35}$, esta fonte responde por $18,3 \%$ do total da energia produzida/importada.

\footnotetext{
${ }^{34}$ Embora exista alguma confusão, a energia nuclear se diferencia daquela que emprega o hidrogênio como fonte. Esta, ainda em fase de estudos e com possibilidade de implantação somente a partir de 2030, tem como, subproduto da transformação, o vapor d'água, e a matéria-prima se encontra em abundância na natureza, livre no ar. Porém, os riscos/entraves envolvidos na sua utilização, em larga escala, perpassam: a dificuldade em separar o material, visto não ser encontrado em estado puro na natureza; a dificuldade de armazenagem do material; os custos de produção elevados pela utilização de equipamentos e tecnologias de ponta em todo o processo; a possibilidade de emprego para fins bélicos; e a produção de carbono durante o ciclo produtivo.

${ }^{35}$ EMPRESA DE PESQUISA ENERGÉTICA (EPE). Balanço energético nacional 2014, p. 35.
} 
Entre as principais vantagens das termelétricas estão: o menor tempo de construção das usinas, quando comparadas às outras modalidades, como as hidrelétricas; poderem ser instaladas em locais próximos às regiões de consumo, pois não demandam isolamento e inundação de área, o que reduz o custo com instalação de linhas de transmissão e distribuição, apesar de aumentar o contato com os gases poluentes gerados no processo. Tem-se, assim, que as maiores desvantagens se relacionam à: liberação de poluentes responsáveis pelo efeito estufa, devido às altas taxas de $\mathrm{CO}$ e $\mathrm{CO}_{2}$, que demandam dispendiosos tratamentos dos gases liberados na atmosfera; e ao custo final da energia produzida, mais elevado do que a proveniente de outras fontes, devido ao custo de aquisição da matéria-prima.

Embora pudesse ser classificada como uma variação das termelétricas, a energia a base de biomassa ganhou autonomia taxonômica na Matriz Energética Elétrica nacional devido ao material que emprega. Este se constitui em matéria orgânica de origem animal ou vegetal utilizado como combustível para queima. Para o uso desta fonte, existem três tipos de processo ${ }^{36}$ : a combustão em fornos e caldeiras, a gaseificação e a decomposição anaeróbica.

A gaseificação e a decomposição anaeróbica são mais utilizadas por pequenos produtores rurais, pois, o processo, possui como subproduto final a geração de adubo orgânico, passível de utilização na própria plantação, com consequente redução de gastos com a aquisição de aditivos minerais/artificiais. Já a combustão é o meio mais utilizado para se dar destino a vários produtos, dentre eles: os bagaços da cana-de-açúcar; os resíduos florestais e a madeira de reflorestamento cultivada para este fim; cascas de arroz, castanha de caju, e coco-da-baía; óleo de palma; lixívia; entre outros.

A combustão de biomassa é o processo adotado, em maior escala ${ }^{37}$, quando, no Brasil, fala-se de substituição dos combustíveis fósseis empregados nas termelétricas. Estes substitutos são utilizados em consonância à distribuição regional de sua produção pelo território nacional, conforme se depreende das Figuras 4 a 10:

\footnotetext{
${ }^{36}$ As usinas de biomassa podem ser utilizadas em sistemas de cogeração, pois, ao realizar a queima do material, gera-se, além de eletricidade, calor, possibilitando o seu aproveitamento para ambas os fins.

${ }^{37}$ Ibid., p. 29.
} 
Figura 4: Potencial de geração de excedente de energia elétrica no setor sucroalcooleiro.

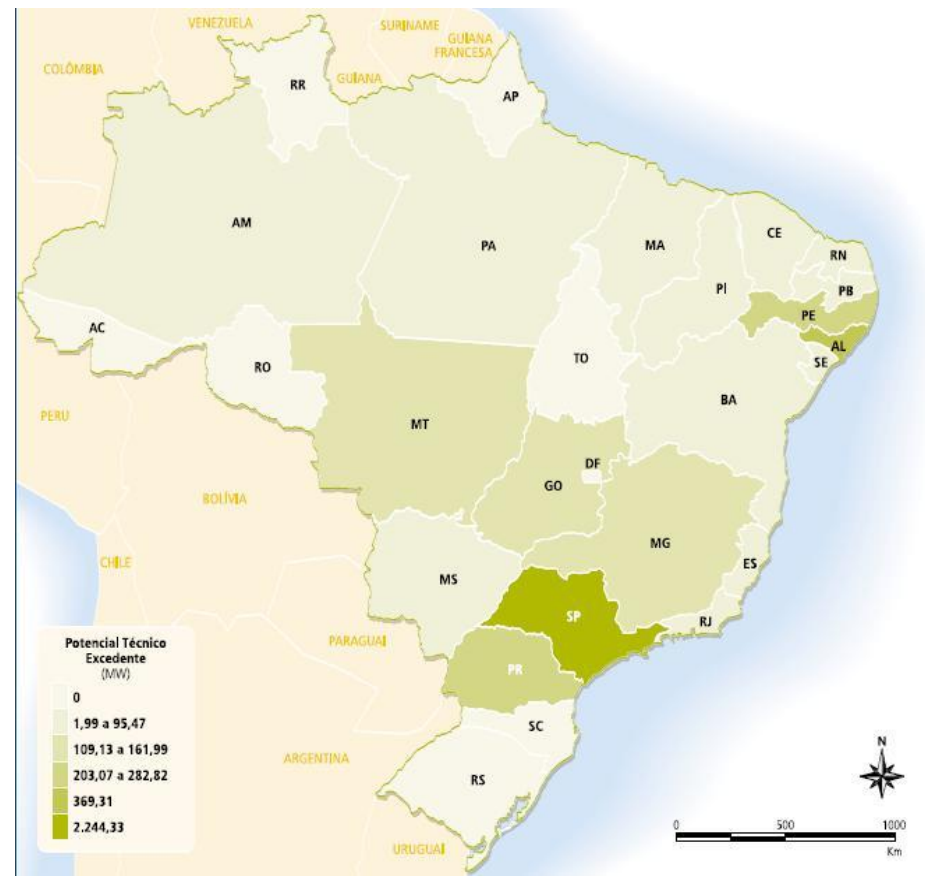

Fonte: CENTRO NACIONAL DE REFERÊN-CIA EM BIOMASSA - CENBIO apud AGÊNCIA NACIONAL DE ENERGIA ELÉTRICA. Panorama do potencial de biomassa. Disponível em: <http://www. aneel.gov.br/biblioteca/downloads/livros/panorama_biomassa.pdf>. Acesso: 14 jul. 2014. p. 81.

Figura 5: Potencial de geração de energia elétrica a partir de resíduos florestais.

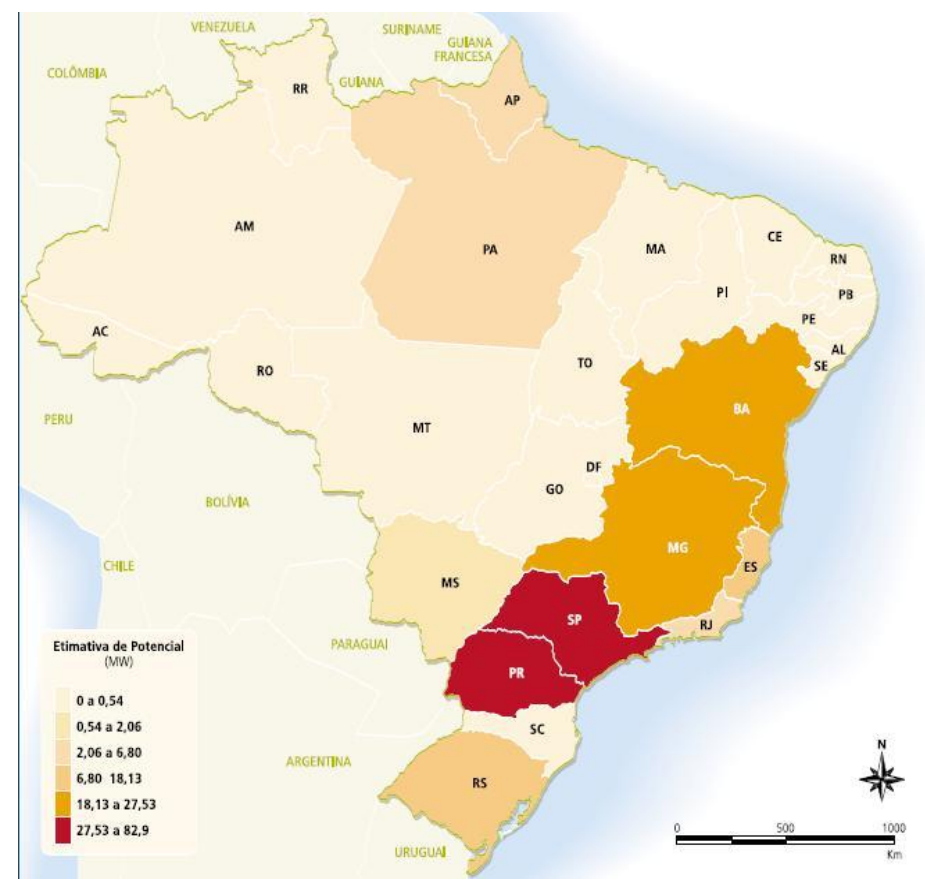

Fonte: CENTRO NACIONAL DE REFERÊN-CIA EM BIOMASSA - CENBIO apud AGÊNCIA NACIONAL DE ENERGIA ELÉTRICA. Panorama do potencial de biomassa. Disponível em: <http://www. aneel.gov.br/biblioteca/downloads/livros/panorama_biomassa.pdf>. Acesso: 14 jul. 2014. p. 80. 
Figura 6: Potencial de geração de energia elétrica a partir de casca de arroz.

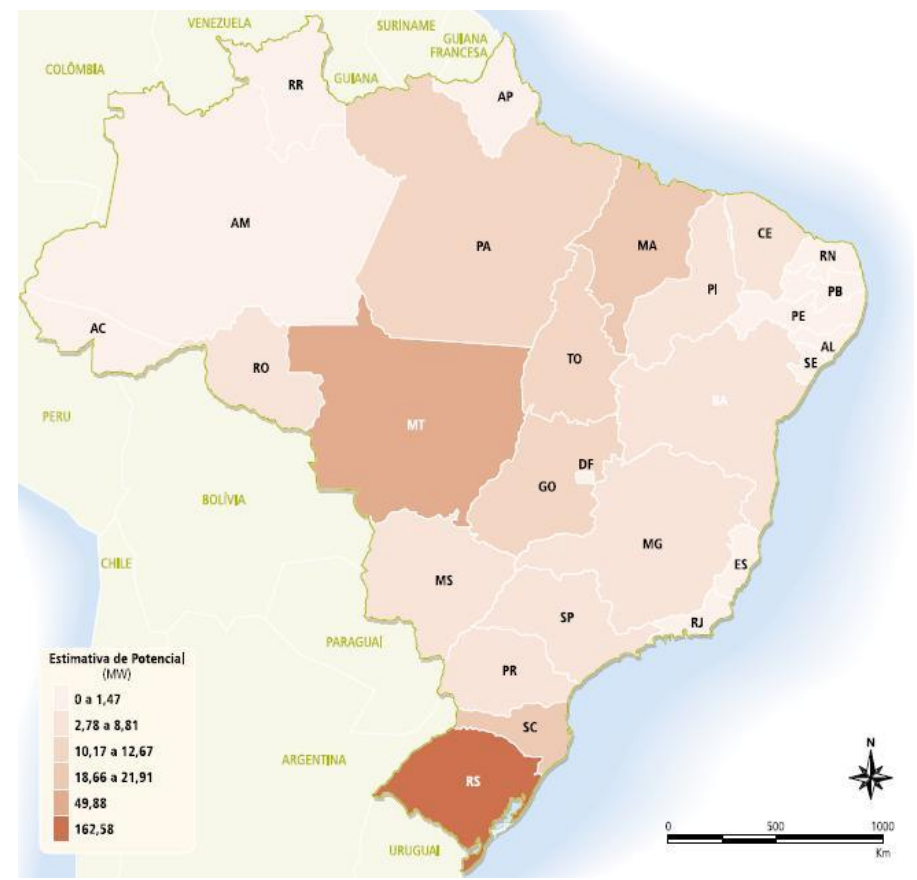

Fonte: CENTRO NACIONAL DE REFERÊN-CIA EM BIOMASSA - CENBIO apud AGÊNCIA NACIONAL DE ENERGIA ELÉTRICA. Panorama do potencial de biomassa. Disponível em: <http://www. aneel.gov.br/biblioteca/downloads/livros/panorama_biomassa.pdf>. Acesso: 14 jul. 2014. p. 84.

Figura 7: Potencial de geração de energia elétrica a partir de casca de castanha de caju.

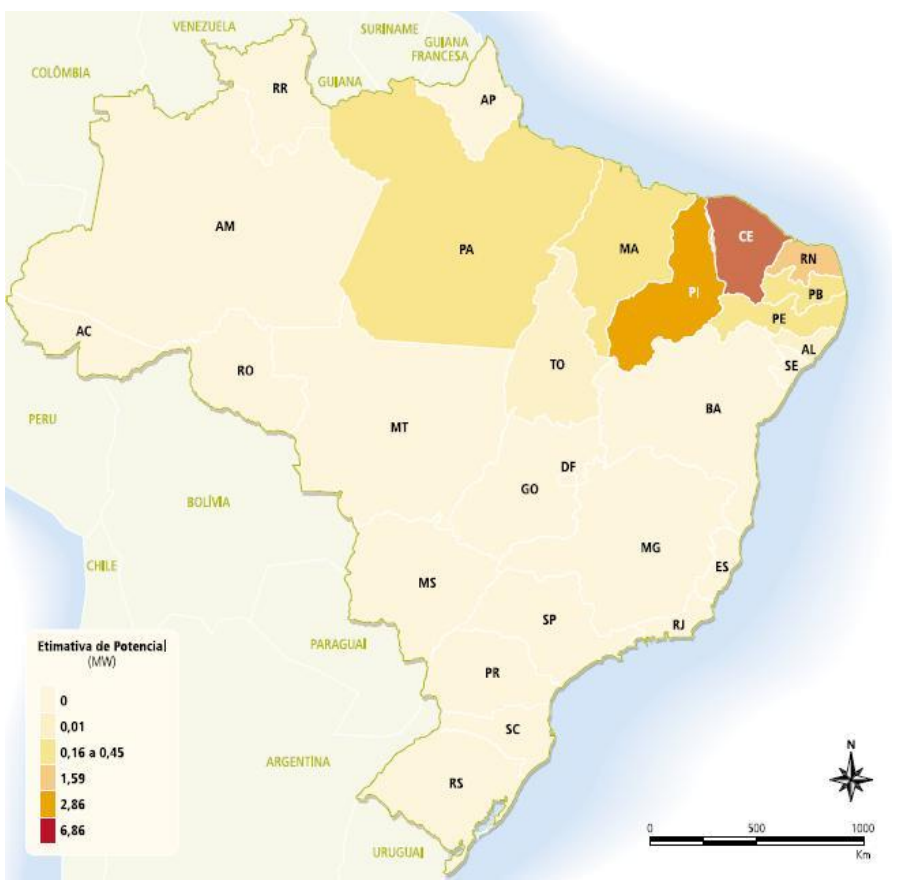

Fonte: CENTRO NACIONAL DE REFERÊN-CIA EM BIOMASSA - CENBIO apud AGÊNCIA NACIONAL DE ENERGIA ELÉTRICA. Panorama do potencial de biomassa. Disponível em: <http://www. aneel.gov.br/biblioteca/downloads/livros/panorama_biomassa.pdf>. Acesso: 14 jul. 2014. p. 85. 
Figura 8: Potencial de geração de energia elétrica a partir da casca de coco-da-baía.

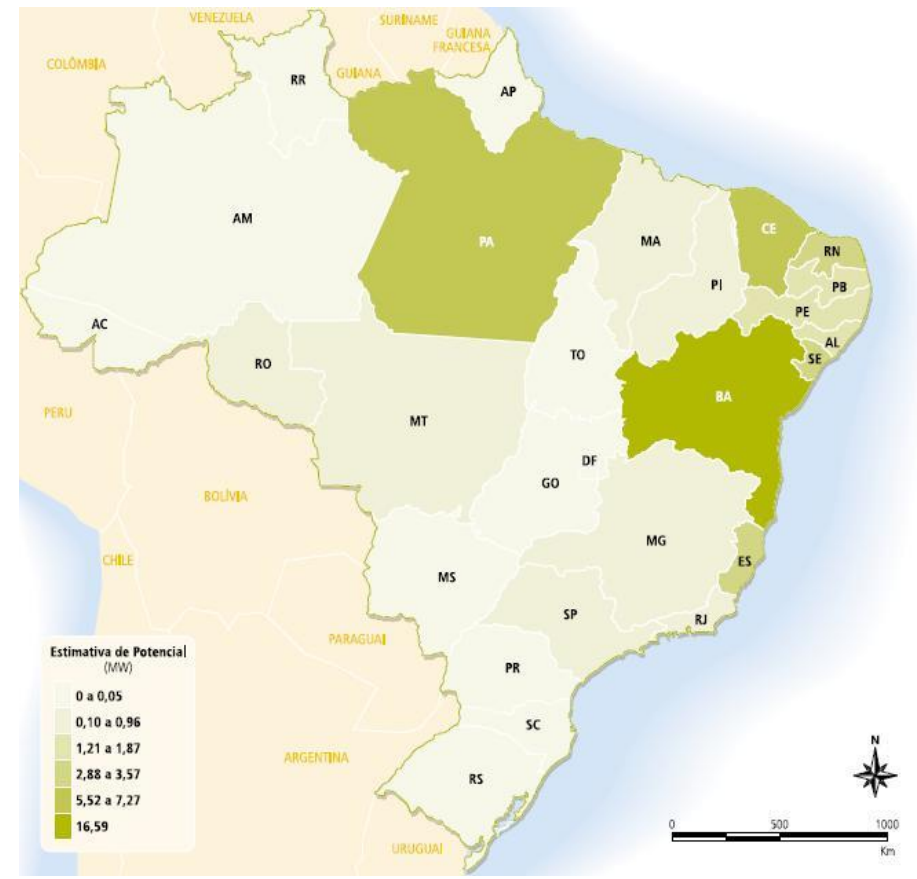

Fonte: CENTRO NACIONAL DE REFERÊN-CIA EM BIOMASSA - CENBIO apud AGÊNCIA NACIONAL DE ENERGIA ELÉTRICA. Panorama do potencial de biomassa. Disponível em: <http://www. aneel.gov.br/biblioteca/downloads/livros/panorama_biomassa.pdf>. Acesso: 14 jul. 2014. p. 86.

Figura 9: Potencial de geração de energia elétrica a partir do óleo de palma.

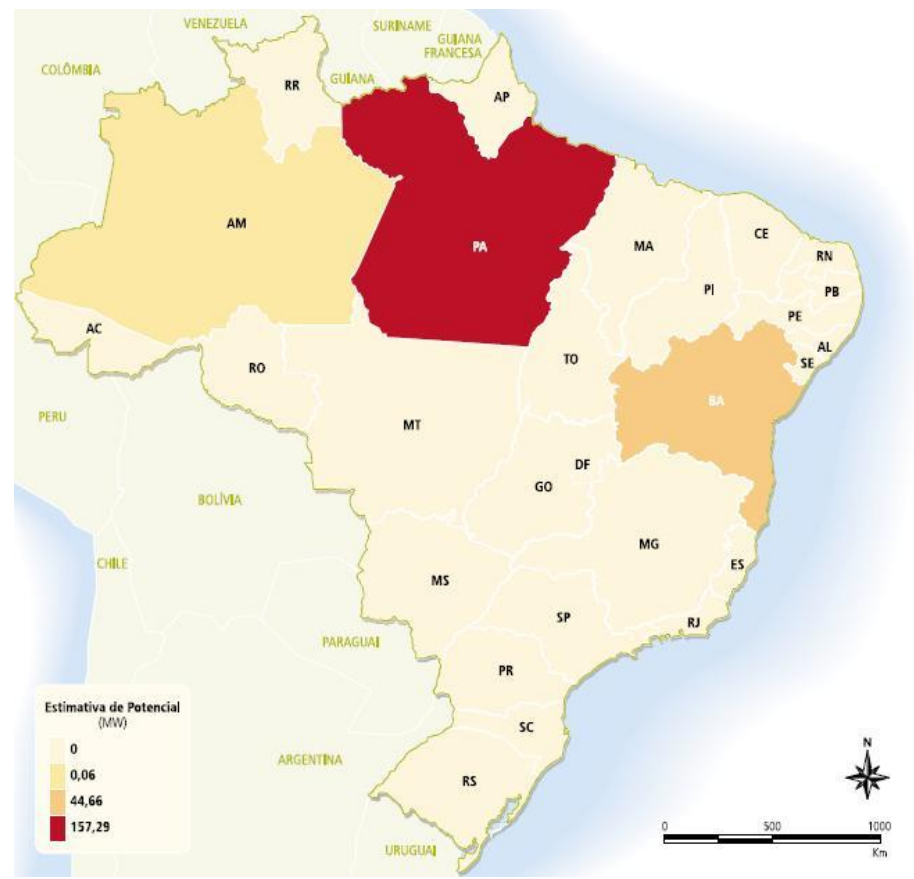

Fonte: CENTRO NACIONAL DE REFERÊN-CIA EM BIOMASSA - CENBIO apud AGÊNCIA NACIONAL DE ENERGIA ELÉTRICA. Panorama do potencial de biomassa. Disponível em: <http://www. aneel.gov.br/biblioteca/downloads/livros/panorama_biomassa.pdf>. Acesso: 14 jul. 2014. p. 83. 
Figura 10: Usinas de biomassa em operação em novembro de 2008.

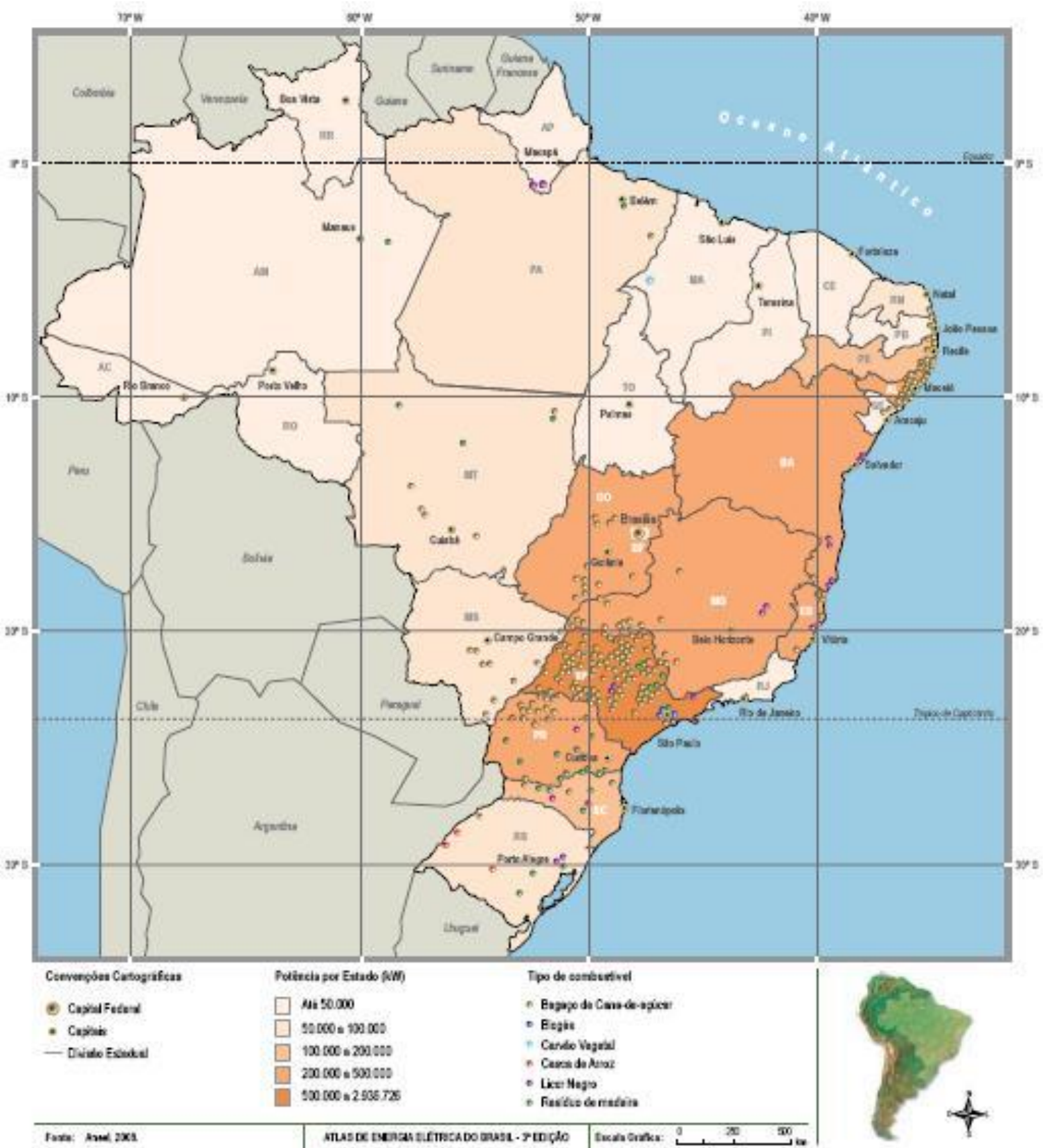

Fonte: AGÊNCIA NACIONAL DE ENERGIA ELÉTRICA. Atlas de energia elétrica do Brasil. 3. Ed. Brasília: ANEEL, 2008. p. 72. 
As principais vantagens do sistema que emprega a biomassa são o uso de resíduos das indústrias e, até mesmo, o lixo orgânico produzido em larga escala pela população, criando-se um círculo virtuoso que perpassa a reciclagem e a redução da quantidade de lixo depositada nos aterros sanitários, acarretando em aumento na sua vida útil. Todavia, a principal desvantagem, em termos ambientais, é, tal como no modelo das termelétricas, a liberação de poluentes causadores do efeito estufa que, também demandariam tratamentos. ${ }^{38}$

Ao lado das fontes não-renováveis e não-limpas - nuclear e termelétrica a base de combustíveis fósseis - e das renováveis e não-limpas - biomassa - estão as consideradas renováveis e limpas. Inserem-se, nesta categoria, a energia solar, a eólica e a hidroeletricidade - base do sistema nacional, como se depreende das Figura 2 e 3, supra, e 11 e 12, infra:

\footnotetext{
${ }^{38}$ Não se confundem a produção de eletricidade a partir da biomassa com a proveniente do biogás devido à diversidade do material empregado. Esta utiliza gases originados da decomposição de dejetos urbanos, industriais, agropecuários e de esgotos, compostos, em grande parte, por metano, gás carbônico, nitrogênio, hidrogênio, oxigênio e gás sulfídrico. Para a sua transformação em eletricidade utiliza-se a combustão direta dos resíduos, a gaseificação ou processos anaeróbicos de decomposição da matéria orgânica. Sua principal vantagem é, também, a diminuição da quantidade de lixo depositada nos aterros. Os seus principais riscos se ligam à instabilidade dos componentes do gás, cuja parcela é liberada no processo, bem como a geração de outros como aqueles com base em carbono que, para a sua dispersão, exigem tratamento adequado, pondo em discussão se esta fonte é, de fato, uma energia limpa, dúvida que, também paira sobre a biomassa.
} 
Figura 11: Potencial hidrelétrico brasileiro por sub-bacia hidrográfica: situação em março 2003.

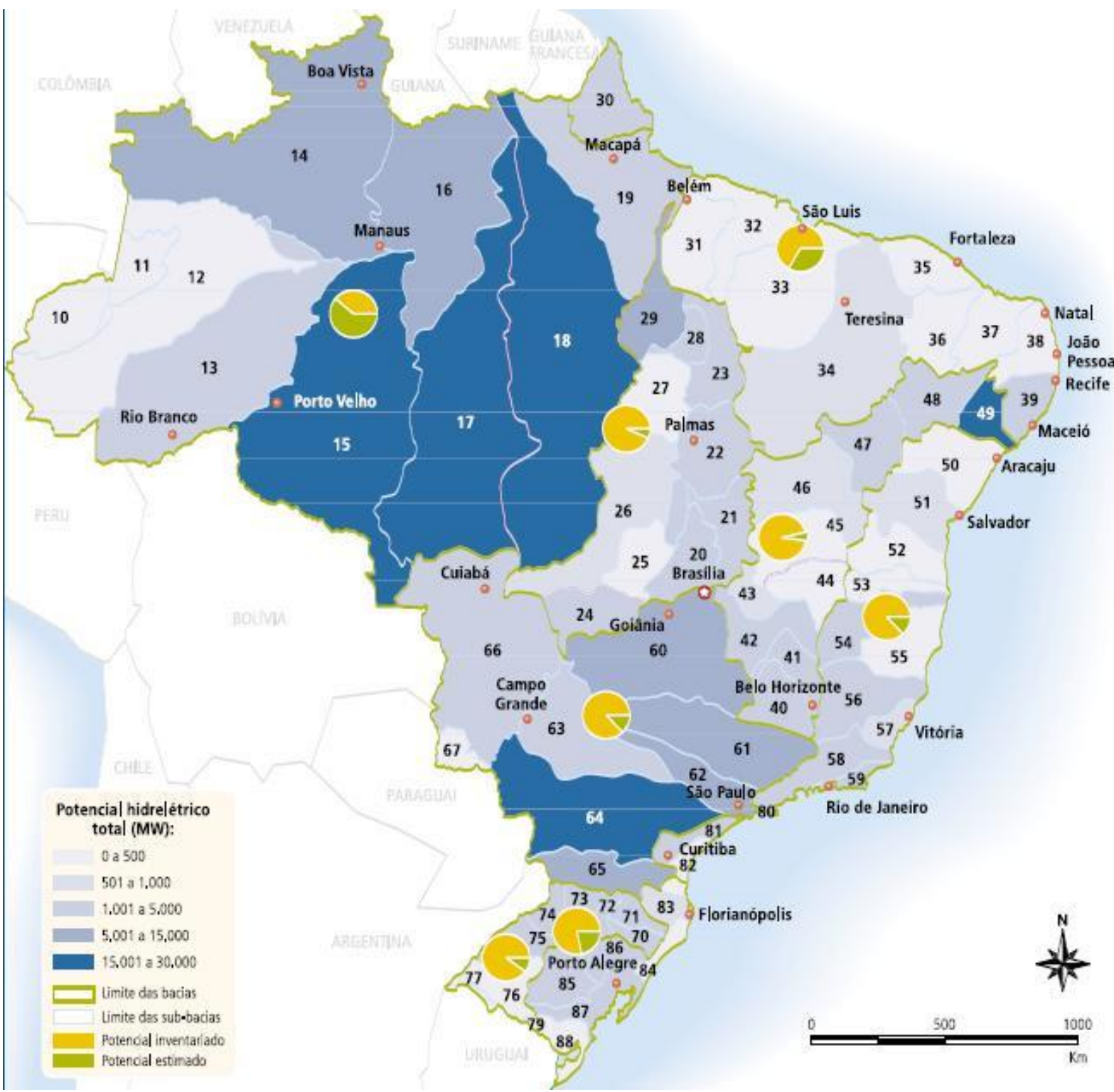

Fonte: CENTRAIS ELÉTRICAS BRASILEIRAS - ELETROBRÁS apud AGÊNCIA NACIONAL DE ENERGIA ELÉTRICA. hidrelétrico brasileiro.

Disponível

em:

http://www.aneel.gov.br/aplicacoes/atlas/energia_hidraulica/4_3.htm>. Acesso em: 14 jul. 2014. p. 48. 
Figura 12: Capacidade instalada por sub-bacia hidrográfica: situação em março 2003.

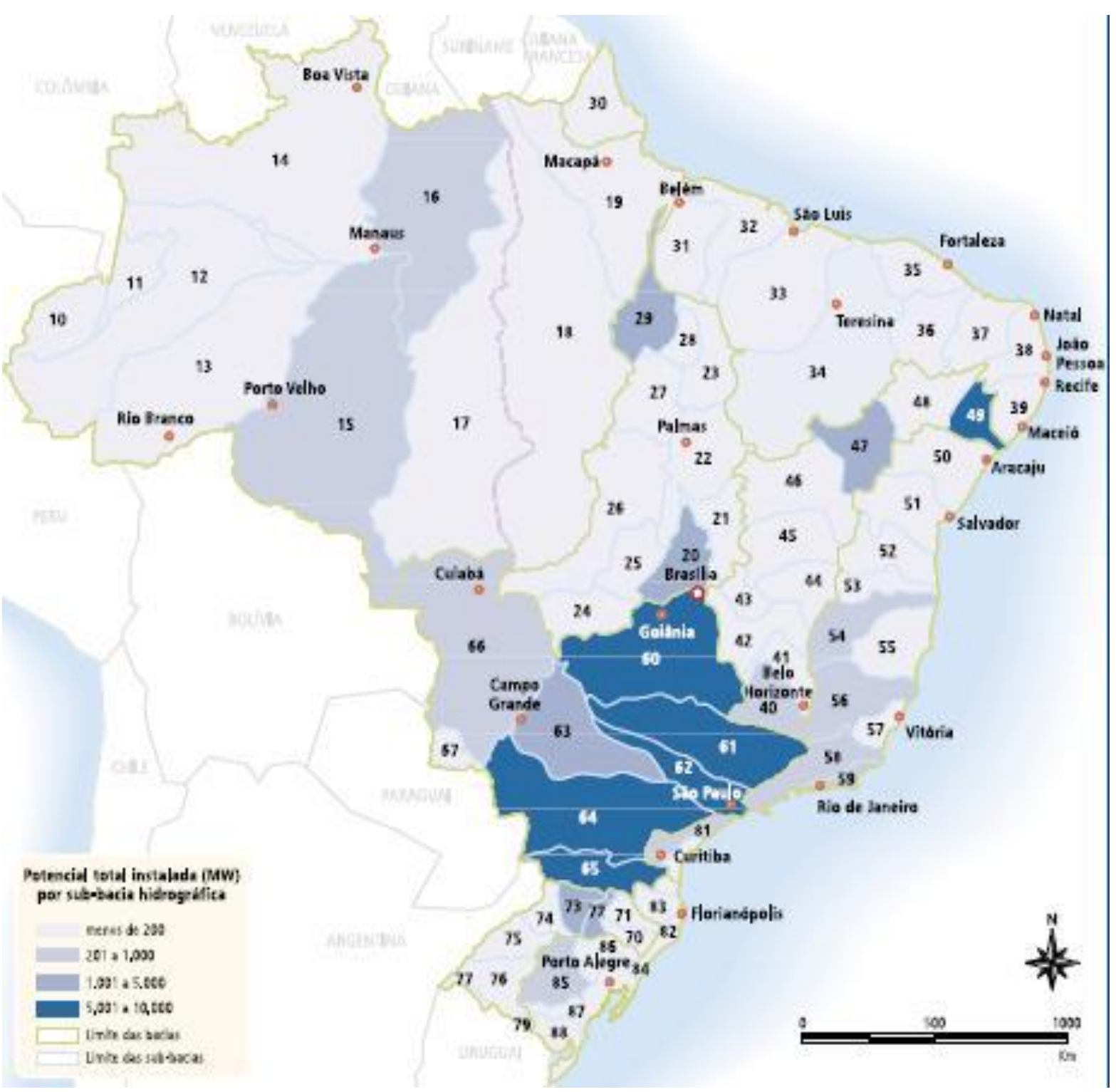

Fonte: CENTRAIS ELÉTRICAS BRASILEIRAS - ELETROBRÁS apud AGÊNCIA NACIONAL DE ENERGIA ELÉTRICA. Potencial hidrelétrico brasileiro. Disponível em: <www.aneel.gov.br/ aplicacoes/atlas/energia_hidraulica/4_3.htm>. Acesso em: 14 jul. 2014. p. 55. 
No Brasil, existem duas formas de produção de energia elétrica com base hidráulica: grandes reservatórios de água, construídos com barragens e turbinas; e o sistema de lâmina d'água ${ }^{39}$, que prescinde da construção de barragens. As centrais do primeiro tipo exigem a construção de barragens e necessitam de um maior prazo para entrarem em operação devido à execução da infraestrutura, à instalação das turbinas geradoras de energia e ao tempo despendido para a inundação da área a ser transformada em represa.

Assim, as aludidas centrais variarão conforme o tamanho de seus reservatórios e a altura de sua queda d'água, o que impactará no seu porte/capacidade de produção. Com fulcro nessas variáveis, tais centrais podem ser subdivididas em: "centrais geradoras hidrelétricas" - CGH - "com até $1 \mathrm{MW}$ de potência instalada"; "pequenas centrais hidrelétricas" - PCH - que possuem entre "1,1 MW a 30MW de capacidade intalada"; e "usina hidrelétrica de energia" - UHE - "com mais de 30 MW de potência instalada de produção." ${ }^{40}$ Tem-se, pois, que, quanto maior o reservatório e mais alta a queda livre da água, maior será a velocidade de passagem pela turbina e maior será o potencial energético produzido.

As principais vantagens do aludido sistema são: operar com o ciclo das águas/regime de chuvas para sua renovação; o custo de produção de energia é baixo, pois a matéria prima está disponível em abundância no meio; considerar-se tal fonte como não poluente pela não liberação de gases causadores do efeito estufa. Como principais desvantagens estão: a erosão dos solos; os elevados custos de instalação das centrais; o impacto ambiental sobre a fauna e a flora das áreas inundadas; além dos impactos decorrentes da remoção das comunidades que habitavam tais áreas.

A segunda espécie de fonte energética renovável e limpa mencionada é a eólica. A instalação de uma usina geradora de energia à base eólica exige a colocação de torres ${ }^{41}$, com um sistema de pás - rotacionadas pela passagem do vento - interligadas a um gerador elétrico, que converte a energia mecânica das pás em energia elétrica.

A quantidade de energia produzida é estabelecida por meio de uma relação matemática, em função da densidade do ar, da área coberta pela rotação das pás - turbina - e da velocidade do vento no local - o que depende, entre outros fatores, das condições morfológicas do lugar, como relevo e

\footnotetext{
${ }^{39}$ As centrais que funcionam por meio de lâmina d'água necessitam de equipamentos mais simples e com maior facilidade de instalação, empregando a corrente pluvial para movimentação de pás e geração de energia elétrica, semelhantemente ao sistema que aproveita a energia cinética das marés, atraindo, também, as desvantagens deste sistema no tocante aos impactos socioeconômicos e ambientais. Entretanto, o volume de investimentos tende a ser reduzido se comparado ao modelo de centrais hidrelétricas, pois sua instalação não exige grandes investimentos infraestruturais - como os provenientes da construção de barragens etc.

40 CÂMARA DE COMERCIALIZAÇÃO DE ENERGIA ELÉTRICA. Disponível em: <http://www.ccee.org.br/ portal/faces/pages_publico/onde-atuamos/fontes?_afrLoop=754080488098693\#\%40\%3F_afrLoop\%3D75408 0488098693\%26_adf.ctrl-state\%3Dn6nfmr2r9_4>. Acesso em: 14 jul. 2014.

${ }^{41}$ Esta instalação pode ocorrer no solo (on-shore) ou no mar (off-shore).
} 
rugosidade do solo, influenciadores do regime de ventos, podendo, até mesmo, alterá-lo. Considerando-se tais dados, tem-se que os maiores potenciais eólicos nacionais se encontram nas regiões Nordeste, Sul e Sudeste - como se observa pela Figura 13 - e, atualmente, conforme a Empresa de Pesquisa Energética brasileira ${ }^{42}$, o Brasil possui uma capacidade instalada de $1.886 \mathrm{MW} .{ }^{43}$

42 EMPRESA DE PESQUISA ENERGÉTICA (EPE). Balanço energético nacional 2013: ano base 2012. Rio de Janeiro: EPE, 2013. p. 14.

43 AGÊNCIA NACIONAL DE ENERGIA ELÉTRICA. Atlas de energia eólica. Ano 2003?. Disponível em: <http://www.aneel.gov.br/aplicacoes/atlas/pdf/06-energia_eolica\%283\%29.pdf>. Acesso em: 19 jul. 2014. p. 96. 
Figura 13: Velocidade média anual do vento a 50m de altura.

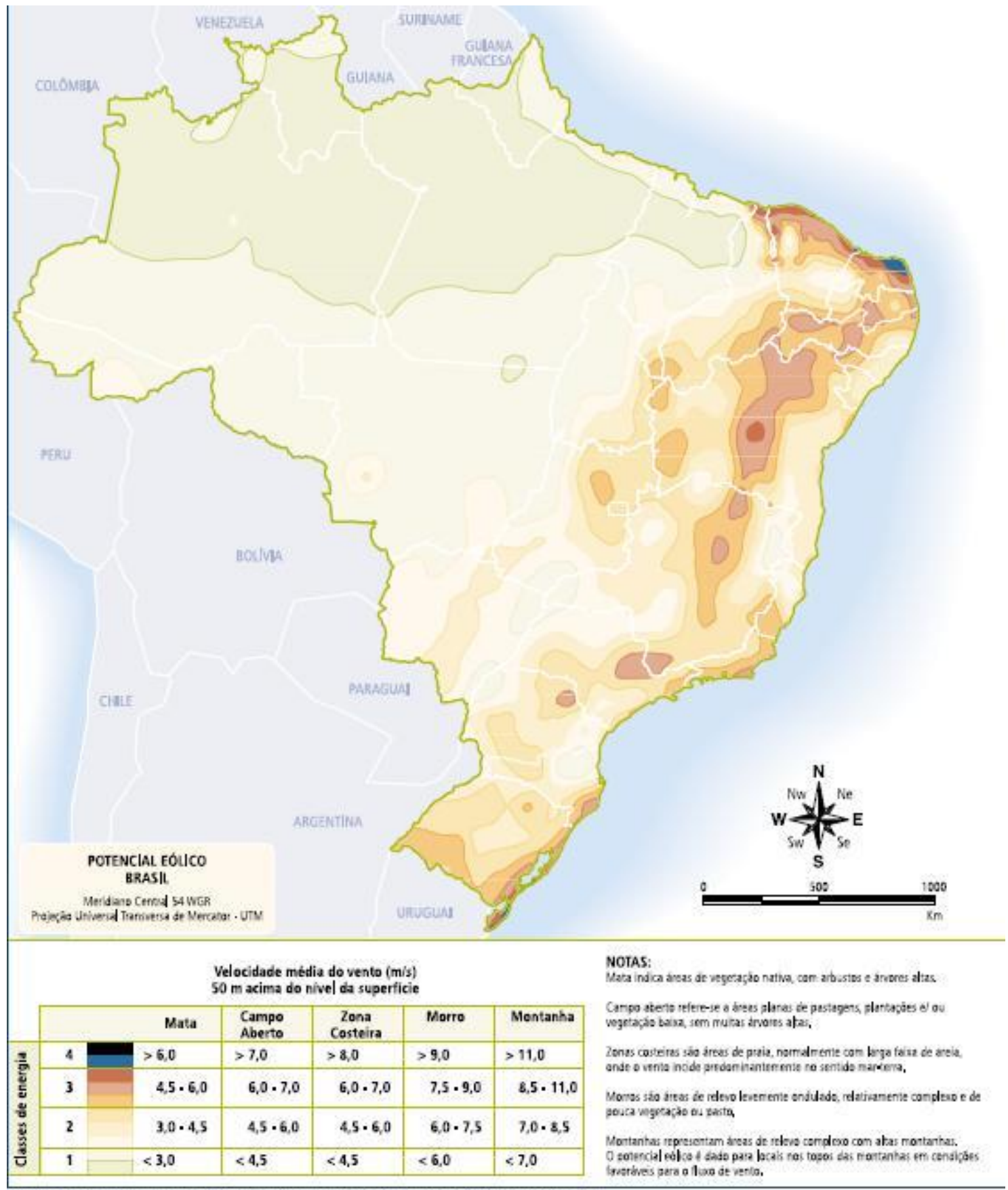

Fonte: FETOSA, E A, N et al. Pancrama do Potenxial Eofico no Brasi. Brasifa: Duplig afica, 2003. (odaptado)

Fonte: FEITOSA, E. A. N. et. al. apud AGÊNCIA NACIONAL DE ENERGIA ELÉTRICA. Panorama do potencial eólico no Brasil. Disponível em: <http://www.aneel.gov.br/aplicacoes/atlas/energia_eolica/6_3.htm>. Acesso em: 14 jul. 2014. p. 96. 
As principais vantagens do emprego da geração de energia eólica são: a inesgotabilidade e abundância da fonte de energia; a não emissão de gases poluentes e a não geração de resíduos como subprodutos do processo; a possibilidade de conjugar a produção de energia a outras atividades como, por exemplo, a agropecuária; a não utilização de combustíveis para o funcionamento dos aerogeradores; e o prazo de retorno do investimento inicial ser de, aproximadamente, seis meses do início da operação. As suas desvantagens decorrem: da intermitência dos ventos, o que acarreta a descontinuação da quantidade de energia produzida; o impacto visual na paisagem pelo número de torres instaladas; o impacto sobre a fauna, pois, devem-se evitar rotas de migração de aves e usar sistemas subterrâneos de transmissão de energia; o ruído constante produzido pela rotação das pás, que pode interferir no processo de reprodução de algumas espécies animais; o prazo de manutenção das torres ser pequeno e constante - a cada seis meses; além de sua instalação não poder se dar próxima a áreas habitadas, devendo-se guardar uma distância superior a duzentos metros destas.

Enfim, tem-se a energia solar, também, considerada renovável e limpa, tanto pela não emissão de gases poluentes, quanto pela fonte ser considerada inesgotável, devido à sua liberação diária, sobretudo no Brasil, em que a quantidade de dias com céu claro é superior a de outras localidades, conforme se depreende da Figura 14: 
Figura 14: Média anual de insolação diária no Brasil (horas).

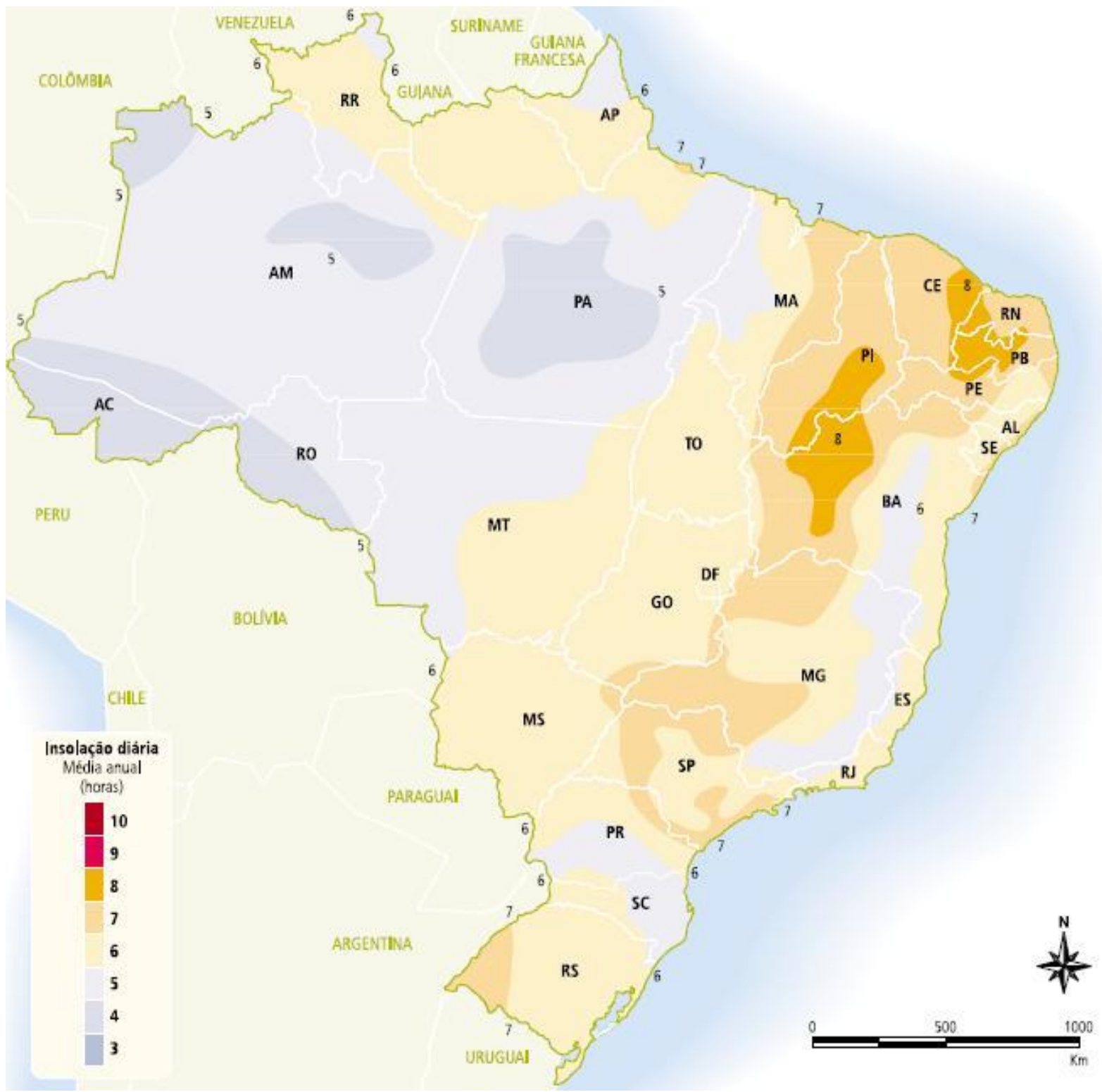

Fonte: ATLAS SOLARIMÉTRICO DO BRASIL apud AGÊNCIA NACIONAL DE ENERGIA ELÉTRICA. Energia solar. Disponível em: <http://www.aneel.gov.br/aplicacoes/atlas/pdf/03-Energia_Solar(3).pdf>. Acesso em: 14 jul. 2014. p. 32.

A produção de energia solar pode se dar por dois processos: a fotovoltaica e a solar térmica. Aquele exige a instalação de painéis fotovoltaicos, posicionados para a orientação que recebe a maior incidência de raios solares. Estes, ao atingirem o painel, agitarão os elétrons da placa, gerando energia que, posteriormente, transferir-se-á a um controlador de cargas, e, deste, a um inversor. Após estas etapas, a energia poderá ser utilizada pelo produtor, que poderá liberá-la na rede pública de distribuição, ou, ainda, armazená-la em baterias para utilização noturna - período, obviamente, sem produção pelo sistema. 
A energia solar térmica demanda a instalação de dispositivos refletores curvos que, ao receberem a incidência de luz solar, refletem-na a um ponto específico - o foco, normalmente situado em uma torre. As fazendas solares deste tipo possuem vários refletores solares que direcionam a energia/calor ao foco, que a transmite para dutos de água existentes dentro da torre. Esta, aquecida, torna-se vapor que movimenta uma turbina mecânica acoplada ao gerador. Este, ao se movimentar, gerará eletricidade. ${ }^{44}$

Além de não emitir resíduos ou gases causadores do efeito estufa, a energia solar apresenta outras vantagens: como dito, a alta incidência dos raios solares, no Brasil, mostra-se um ponto forte à sua difusão ${ }^{45}$; permitiria que pequenos consumidores, por exemplo moradores de casas e apartamentos, instalem placas para o seu consumo, viabilizando a sua liberação na rede pública mediante abatimentos nas contas de eletricidade ${ }^{46}$; não depender do brilho do sol, mas somente da reflexão dos raios solares, permitindo que, também em dias nublados ocorra a produção. Entre as críticas sofridas pelo sistema está o gasto energético extensivo para a produção dos módulos fotovoltaicos, pois, são produzidos a base de silício, e, no fim da vida útil do sistema - em média 30 anos de geração - parte é reciclada e parte depositada em aterros sanitários, contribuindo para a contaminação do solo.

Tem-se, portanto, que nenhuma das fontes apresentadas é desprovida de vantagens e riscos e considerá-los no processo de tomada de decisão recoloca o tema da acepção ampliada de sustentabilidade discutida nas seções iniciais deste ensaio. Somente analisando, seriamente, os pontos fracos e fortes, os custos inerentes a cada modalidade e os processos técnicos de produção e considerando as interseções com outras políticas públicas, realizar-se-ão opções que adéqüem o

\footnotetext{
${ }^{44}$ Este sistema apresenta variações. Em alguns modelos, o movimento das placas é individual, ampliando o período/capacidade de captação de cada uma delas. Em outros, além dessa movimentação individual, não há a projeção para um foco, mas o aquecimento de líquidos, diretamente nas placas, ampliando a duração da fase de captação e reduzindo as perdas do processo. Porém, em ambos os casos, o investimento financeiro em tecnologia pode se mostrar um obstáculo à sua utilização.

45 No Brasil a radiação solar incidente média anual varia de 16 a $20 \mathrm{MJ} / \mathrm{m}^{2}$ durante o dia, sendo a região Nordeste a que possui a maior radiação solar. (Ibid., p. 34.)

Para a Copa do Mundo de 2014, parte dos estádios reformados experimentou a autoprodução de energia solar elétrica por meio de placas fotovoltaicas instaladas em suas coberturas. A energia produzida se destinará ao consumo das arenas e à liberação na rede pública. (COMPANHIA ENERGÉTICA DE MINAS GERAIS. CEMIG e governo estadual inauguram usina solar do Mineirão. Disponível em: <http://www.cemig.com.br/ sites/ Imprensa/pt-br/Paginas/usina-solar-do-Mineirao.aspx>. Acesso em: 25 jan. 2015.)

${ }^{46}$ A utilização em larga escala da energia solar por pequenos consumidores pode gerar uma sobra de energia na rede pública, seja porque estes deixarão de utilizá-la, somente o fazendo quando necessitarem; seja porque liberarão o excedente produzido na rede. Assim, atenuar-se-iam os impactos do aumento de utilização da eletricidade no horário de pico de consumo - das 17:00 às 21:00 horas - pois as baterias acopladas aos sistemas residenciais proporcionariam o armazenamento do sobejo, aumentando a oferta de energia para os demais setores, como o industrial, que, também, pode utilizar mecanismos de autoprodução como este.
} 
aumento da capacidade energética nacional à conservação ambiental e à melhoria das condições de vida da população, o verdadeiro objetivo principal de qualquer ação estatal.

\section{CONSIDERAÇÕES FINAIS}

A política energética nacional tem-se pautado por uma lógica que considera somente o binômio custo de implementação/produção e o potencial energético gerado. Nessa visão reducionista, privilegia-se a ideia de "desenvolvimento econômico", relegando-se, ao segundo plano, outras acepções do vocábulo "desenvolvimento", como o "social" e o "sustentável" - ora visto como complacente à primeira acepção, ora desconsiderando a presença do homem e o seu papel de transformador do meio.

Uma noção ampliada de "sustentabilidade" obriga, porém, que se reconheçam as interfaces entre todas as acepções acima, as interseções e os delineamentos entre as diversas políticas públicas envolvidas ou impactadas pelas opções concernentes à implementação de dada decisão. Nesse sentido, documentos técnicos, mapas e outras peças, difíceis ao trato dos juristas, são fundamentais, por indicarem acertos ou desacertos, rumos e tendências a serem observadas no processo de normatização das políticas públicas, especialmente da energética.

Assim, retomando a comparação estabelecida entre as Matrizes Energéticas Elétricas brasileiras dos Anos-base 2013 e 2012 - Figuras 2 e 3 e Tabela 1 - pode-se esquadrinhar o sentido da evolução do setor energético no que tange à geração e ao consumo.

Analisando-se os gráficos, infere-se, como mencionado na seção anterior, que a matriz brasileira é, primordialmente, de base hídrica. As fontes termelétricas, a base de combustíveis fósseis, figuram como uma segurança/reserva técnica de suprimento, a ser acionada em casos emergenciais, enquanto, as demais são ampliações do leque de opções de fornecimento, com pouca presença no total gerado - 11,1\% do total gerado no Ano-base 2013 - não se podendo afirmar que ocuparão, sequer, o papel de reserva técnica no curto prazo.

Pela análise dos dados, infere-se que houve um aumento na oferta de energia elétrica no importe de 2,88\% (17,1TWh). Porém, este aumento não foi proporcional em todas as fontes de energia, havendo, de fato, uma redução da participação da energia hidrelétrica na composição da Matriz, no importe de 5,4\% (24,7 TWh). Tal dado indica que a crise hídrica que assola o país encontra sua origem em período anterior ao ano de 2014, porquanto, o setor energético, já no ano intervalo 2012/2013, sentia a redução da participação da hidroeletricidade na composição da matriz. Tal fato obrigou a ampliação do fornecimento das demais fontes, porém, com intensidades diversificadas, com predomínio das fontes termelétricas com funcionamento a base de combustíveis fósseis, que 
aumentaram para 18,3\% sua participação, na comparação 2012-2013, face a uma participação anterior de $12,8 \%$.

Dentre as fontes consideradas renováveis, a que mais cresceu no intervalo citado, em termos percentuais, foi a energia eólica, com um aumento de $29,4 \%$, ao passo que a participação da energia proveniente de biomassa aumentou $15,7 \%$ no mesmo período. Entretanto, quando se examina cada uma destas fontes frente à composição da Matriz nacional, tem-se que a energia eólica aumentou sua participação em apenas $0,2 \%$, ao passo que a biomassa teve uma majoração de $0,8 \%$. Isto é, enquanto a energia eólica representava, em 2012, 0,9\% da matriz passando, em 2013, para 1,1\%; a participação da biomassa saltou de 6,8\%, em 2012, para 7,6\%, em 2013.

No tocante à energia nuclear, operou-se uma redução de 8,75\% no período, passando de 2,7\% da Matriz, em 2012, para 2,4\%, em 2013. Ou seja, sua participação ainda equivale a mais do que o dobro da participação da energia eólica e é muito maior do que a energia solar que, sequer, figura na composição da Matriz, em situação de relevo - não havendo discussões difundidas acerca da instalação de outros modelos como a maremotriz.

Estes dados, frutos da crise hídrica nacional, indicam que as fontes de energia poluentes e não-renováveis ampliaram sua participação na composição da Matriz, em prejuízo à efetivação da ideia de "sustentabilidade". Mesmo que se considere o aumento da participação da biomassa e a redução da energia nuclear ${ }^{47}$, ainda assim, a sobredita afirmação não pode ser afastada, já que a biomassa é uma fonte de energia não-limpa. Nem mesmo o reestabelecimento da participação da energia hidrelétrica afastaria tal tese, pois, o sistema de segurança técnica permaneceria sendo nãorenovável e não-limpa - ou quando muito, somente não limpa, caso se substituíssem as termoelétricas movidas a combustíveis fósseis por aquelas movidas a biomassa. Ademais, o critério de classificação das fontes de energia em limpas e não-limpas considera a emissão de gases de efeito estufa na atmosfera, não mensurando a produção de poluentes liberados pela decomposição da vegetação submersa, problema específico do modelo hidrelétrico de grandes reservatórios adotado nacionalmente.

Apesar disso, no Brasil, difundiu-se a ilusão de que a matriz energética nacional se mostra adequada à lógica preservacionista, em razão da confusão entre, de um lado, as noções de energia renovável e energia limpa e, lado outro, a inserção de cada uma das fontes tratadas em cada uma

\footnotetext{
${ }^{47}$ As notícias sobre a construção de uma terceira usina nuclear no território brasileiro indicam que a redução da participação da energia nuclear, no período, pode significar uma dificuldade na aquisição da fonte de energia ou uma redução operacional por qualquer outra razão técnica, o que afasta afirmações sobre a redução de sua importância nacional. Assim, reforçar-se-ia a tese da ampliação da participação de fontes não-renováveis e nãolimpas, bem como uma atuação brasileira contrária às tendências internacionais de redução da energia nuclear em suas matrizes, de forma a fazer com que fontes renováveis e limpas sejam implantadas.
} 
dessas categorias. Corrobora essa sensação o fato de não se considerarem nessas discussões os aspectos sociais atinentes aos atingidos por barragens e a desarticulação da vida socioeconômica dessas comunidades.

Examinando-se, agora, os aspectos relativos aos gastos de energia, verificou-se uma redução nas perdas do sistema, equivalente a 0,75\% na comparação entre 2012 e 2013, acompanhada da majoração do consumo nos demais setores, com exceção do industrial que, praticamente, manteve o seu consumo inalterado, tendo em vista que seu aumento foi de apenas $0,2 \%$ na mesma comparação. Comparados a redução das perdas do setor elétrico com o sobejo de consumo da indústria, tem-se que este foi suprido pela economia decorrente da maior eficiência técnica do sistema, com um saldo positivo de $0,2 \mathrm{TWh}$ que puderam ser consumidos pelos demais setores que aumentaram, em maior proporção, o seu consumo.

Os setores comercial, público, energético, agropecuário e de transportes, conjuntamente, em 2012, foram responsáveis por $28,8 \%$ do consumo da matriz e, no ano de 2013 , este consumo foi aumentado em 1,0\% (10,2TWh). No entanto, o setor residencial teve sua participação no consumo da Matriz aumentada em $6,11 \%$ no intervalo investigado - no primeiro ano, consumiu $19,8 \%$ da energia disponível e, no ano seguinte, 20,5\%. Este aumento percentual equivale ao consumo de 7,2TWh, portanto, mais de catorze vezes o aumento do consumo industrial e, apenas, 3,0TWh menor que o consumo somado dos demais setores.

Inúmeros fatores podem contribuir para explicar o aumento do consumo residencial. Pode-se inferir que a execução de construções e projetos energeticamente ineficientes contribua para o excesso de consumo de energia para o condicionamento das variáveis ambientais - resfriamento e aquecimento - para a permanência/uso das edificações. ${ }^{48}$ Ademais, a permanência destas práticas, somada às políticas de acesso ao crédito para aquisição de eletrodomésticos e para a construção de residências - decorrente dos programas governamentais voltados ao suprimento do déficit habitacional quantitativo - pode ter contribuído ao aludido aumento de consumo.

Todas estas análises demonstram que medidas econômicas e sociais, a priori, não diretamente relacionadas à política energética, impactam diretamente na demanda por energia. Contudo, a morosidade no atendimento de tais demandas e o custo da energia fornecida pelo sistema público notadamente diante de situações emergenciais que levam ao emprego das fontes da reserva técnica têm levado alguns consumidores a se enveredarem pela autoprodução de energia. Inserem-se, aí, as tendências no setor industrial de reaproveitamento de dejetos e subprodutos do processo fabril para

\footnotetext{
${ }^{48} \mathrm{~A}$ constatação deste fato põe em discussão o próprio aumento de consumo nos demais setores consumidores, já que a inobservância de postulados de eficiência energética também podem impactar nas edificações que lhes servem de suporte físico, exigindo o condicionamento artificial das referidas variáveis ambientais.
} 
a produção de energia ou a construção de instalações hidrelétricas de pequeno porte, autorizadas pelo Poder Público e cuja produção se volta para o próprio consumo do produtor.

Também se colocam nessa linha os sistemas residenciais que utilizam a energia solar para aquecimento de água, proporcionando uma redução das tarifas de energia pela queda do consumo da eletricidade - o que, apesar de não ser um sistema de produção, é um meio de economia para o setor. Ainda no setor residencial, agora propriamente relacionado ao tema das fontes de energia, tem-se o emprego de sistemas fotovoltaicos ${ }^{49}$, o que, porém, ainda se mostra uma alternativa onerosa, devido ao custo do sistema, dificilmente acessível a maior parte da população - o que indica que, também o consumo de energia e a possibilidade de produção se relacionam às questões de segregação socioeconômicas.

Este último aspecto, entretanto, não deve ser tomado somente pela perversidade que indica, mas, outrossim, pelas possibilidades que apresenta. Afinal, abre-se, aqui, a percepção de como a produção de energia pode ser conjugada com ações voltadas à melhoria das condições socioeconômicas de populações pauperizadas residentes em áreas onde as condições físicas dificultem a fixação/permanência do homem. Ilustra-se a possibilidade pelas conclusões a que se pode chegar pela análise das Figuras 14 e 15 que, ao apresentarem os potenciais de energia eólica e solar, indicam que regiões tradicionalmente empobrecidas, como o semiárido nordestino, apresentam possibilidade de figurarem como áreas produtoras de energia elétrica, a partir destas fontes, o que pode constituir medida salutar caso se conjugue a geração com ações voltadas à manutenção dessa população nestas localidades - por exemplo, os pequenos proprietários alugarem parte de suas propriedades para o funcionamento das instalações produtoras, utilizando o restante para a produção de gêneros agrários, empregando nessa atividade parte dos recursos provenientes do sobredito contrato.

Obviamente tais medidas exigiriam a fixação de critérios objetivos que possibilitassem a produção energética, não gerassem a expulsão dos habitantes tradicionais destas áreas e que possibilitassem a convivência entre a produção agrária e a exploração energética - considerando, no caso, obviamente, o potencial de produção de ambos os empreendimentos. Nesta hipótese, uma ampliação do sentido do que se considera, no plano jurídico, função social dos imóveis agrários mostra-se imprescindível, para adequar aquilo que se entende por "utilização da terra" e "eficiência na exploração" com ambas às atividades - equiparando-se, por exemplo, a atividade de geração

\footnotetext{
${ }^{49} \mathrm{O}$ que, porém, demanda estudos destinados a mensurar os impactos da difusão desses mecanismos em áreas de grande aglomeração populacional, que abordem os efeitos das placas no conforto térmico e lumínico nas edificações circunvizinhas e em algumas redes de serviços públicos. Elementos estes a serem confrontados tanto ao Direito de Vizinhança, quanto à higidez da salubridade paisagística.
} 
elétrica a uma atividade extrativa, o que privilegiaria, outrossim, os incisos III e IV do artigo 186, da Constituição da República. ${ }^{50}$

Abre-se, assim, a possibilidade de se corrigir a "falta de compromisso das políticas públicas", notadamente as energéticas, "com a problemática ambiental", pois a preservação se alia ao "desenvolvimento econômico", dentro de uma noção ampliada de "sustentabilidade" que agrega, necessariamente, os direitos sociais, entre os quais, o "direito ao trabalho" ${ }^{51}$ Todavia, aí está a necessidade de se adotar uma prática que, considere o cálculo focado no binômio custo/benefício e abarque os impactos sofridos pelos atores envolvidos/atingidos pela medida, notadamente aqueles que figurem nos mais baixos estratos sociais.

Tome-se, por exemplo, o caso do emprego de resíduos sólidos urbanos para a produção de energia advinda de biomassa. Para que tal empreendimento seja viável, é necessário que a produção de resíduos orgânicos se dê em quantidade suficiente para viabilizar o empreendimento ${ }^{52}$, incluindose, aí, instalação, manutenção e funcionamento dos filtros - o que somente pode ser apurado e depende de programas de coleta seletiva aptos a separar o material a ser reaproveitado na indústria

\footnotetext{
${ }^{50}$ O GUT - Grau de Utilização da Terra - e o GEE - Grau de Eficiência da Exploração - são índices presentes na apuração do Imposto Territorial Rural, que apontam se o proprietário aproveita racional e adequadamente o solo, nos termos do inciso I, do artigo 186, da Constituição: "Art. 186 - A função social é cumprida quando a propriedade rural atende, simultaneamente, segundo critérios e graus de exigência estabelecidos em lei, aos seguintes requisitos: | - aproveitamento racional e adequado; || - utilização adequada dos recursos naturais disponíveis e preservação do meio ambiente; III - observância das disposições que regulam as relações de trabalho; IV - exploração que favoreça o bem-estar dos proprietários e dos trabalhadores."

51 PEREIRA, Marlene de Paula; SANTOS, Ângela Moulin Penalva. Desafios da política urbana: análise dos mecanismos de gestão do território que unificam a legislação ambiental e urbanística. In: ENCONTRO MINEIRO DE ADMINISTRAÇÃO PÚBLICA, ECONOMIA SOLIDÁRIA E GESTÃO SOCIAL - EMAPEGS. II, 2010, Viçosa. Anais eletrônicos Encontro Mineiro de Administração Pública, Economia Solidária e Gestão Social: Administração Pública, gestão social e Economia solidária: avanços e desafios. Viçosa: UFV, 2010. p. 302-313. Disponível em: <http://www.emap egs.ufv.br/docs/iiemapegsufv.pdf>. Acesso em: 01 set. 2013. p. 304-305.

52 Dois elementos devem ser considerados nesse aspecto. O primeiro consiste em ações insertas na política preservacionista que, voltadas à redução da produção de lixo, impactem no fornecimento de material a ser empregado nas usinas. Isto é, o sucesso da política ambiental pode importar em uma crise de suprimento do combustível utilizado como fonte na política energética, o que, aliás, constitui um risco para qualquer processo de geração caracterizado por combustão e exige que os gestores antecipem soluções para evitar uma crise de abastecimento. Estas ações, comumente denominadas "consumo consciente", têm se restringido à redução de consumo de materiais recicláveis ou de difícil decomposição - inspirando, até mesmo, ações de logística reversa etc $-e$, caso se mantenham tais orientações, estas medidas devem ser pouco impactantes no fornecimento de combustível para a geração energética.

O segundo elemento a ser considerado é a necessidade de a produção em escala poder se constituir em óbice para que localidades de poucos habitantes empreguem estas fontes de produção e, com isso se deparem com a falta de alternativas para a destinação final dos rejeitos urbanos. É fato que se a produção não atender certa quantidade diária, a produção energética como destinação final do material ficaria prejudicada, o que, porém, não inviabilizaria outros meios de enfrentamento da questão, pois, tais materiais poderiam ser empregados em outros processos como a sobredita compostagem para a geração de adubos orgânicos. Aí estaria uma fonte alternativa de recursos para empresas públicas e concessionárias que explorem a atividade, as quais poderiam se beneficiar, também, da comercialização de material reciclado, na inexistência de ações públicas voltadas ao fomento de cooperativas de catadores desse material, insertas em programas de geração de emprego e renda.
} 
daquele que gerará energia. Porém, ainda que se atendam tais variáveis, não se pode desconsiderar o impacto da medida na vida dos que sobrevivem da cata deste material. ${ }^{53}$

Portanto, medidas voltadas ao aproveitamento desse potencial devem se atentar à sobredita realidade, implementando ações que recoloquem aqueles que vivem dos "lixões" em outras atividades laborais, no mercado ${ }^{54}$, ou associando-os à cadeia produtiva da geração de energia e/ou coleta seletiva ${ }^{55}$, possibilitando-Ihes beneficiar-se dos ganhos advindos da atividade, invertendo a forma como tais ações vêm sendo desenvolvidas. Esta inversão da lógica tradicional pela adição de sentidos ilustra uma das principais consequências da tese aqui apresentada e que deve pautar as ações relacionadas à política energética nacional.

Todas as ilações contidas neste ensaio indicam, assim, não somente a diversidade do potencial energético brasileiro, mas, também, a multiplicidade de questões a serem conjugadas no processo decisório: a peculiaridade dos biomas e dos possíveis impactos decorrentes dos empreendimentos; a especificidade das localidades, das fontes de energia e como se dará a integração destas com o sistema nacional; a singularidade dos problemas sociais envolvidos, o que abre margem para se discutir a participação dos beneficiários e atingidos nesse processo decisório; a necessidade de se buscar novas fontes de energia e a sua relação com a racionalização e eficiência no consumo da energia, hoje, produzida.

\footnotetext{
${ }^{53}$ A desequiparação na repartição das consequências advindas dos resíduos se mostra mais séria, quando se recorda que, a falta de ações estatais voltadas ao seu tratamento e adequado descarte, somada aos casos de extrema segregação social, fazem com que levas de indivíduos se vejam obrigados a sobreviverem da "cata de lixo nos lixões, passando a morar nas proximidades ou até mesmo dentro dessas áreas insalubres e de alta periculosidade, passando a atividade de catador a se constituir uma tradição passada entre gerações [sendo, muitas vezes, estas pessoas, juntamente com os catadores de material reciclado a verdadeira coleta seletiva existente em várias localidades no Brasil]. Segundo o depoimento de uma catadora do aterro controlado (diferente do aterro sanitário, que é o ideal) de Itaoca, em São Gonçalo, enquanto o salário mensal auferido como babá era de $R \$ 400,00$, como catadora de lixo conseguia obter $R \$ 200,00$ por semana, às custas de trabalhar oito horas por dia ao lado de moscas e do fedor presentes nos aterros. Aproveitam para si de tudo que o lixão proporciona (móveis e comida), mas também encontram feto, placenta e pedaços de corpo humano, pois é comum descartarem lixo hospitalar nesses espaços. E ainda que haja proibição para crianças entrarem em lixões, preferem que os menores catem lixo do que convivam com o tráfico de drogas" (OKADA, Denise Setsuko. Resíduos sólidos: novas perspectivas que se impõem. In: COUTINHO, Ronaldo do Livramento; AHMED, Flávio (Org.). Cidade, direito e meio ambiente: perspectivas críticas. Rio de Janeiro: Lúmen Juris, 2011. p. 237, 240-241 e 242.)

${ }^{54} \mathrm{O}$ que, como já se afirmou, espraia-se para políticas e ações de implementação de outras fontes como a maremotriz e as hidrelétricas que empreguem o modelo de lâmina d'água. Nestes casos, constatada a viabilidade do empreendimento, os indivíduos atingidos, para além da indenização a que têm direito, devem ser inseridos em programas voltados à sua reinserção no mercado de trabalho de forma adequada aos parâmetros normativos incidentes sobre a matéria.

55 Dessa forma, objetiva-se quebrar o paradoxo da indústria da reciclagem, que, conforme Ronaldo do Livramento Coutinho, "ao mesmo tempo em que contribui para a redução dos resíduos sólidos, este ramo da produção [a indústria da reciclagem] - ancorada no discurso da sustentabilidade e integrado às práticas inscritas no âmbito da responsabilidade social - impulsiona o seu processo de produção mediante a utilização de matérias-primas obtidas com trabalho informal, superexplorado, realizado em condições subumanas". (COUTINHO, Ronaldo do Livramento. Anotações críticas..., p. 7.)
} 
Conjugar estas particularidades com os caracteres especiais de cada política pública envolvida, encontrando seus pontos de contato, suas interseções, suas diferenças, suas incompatibilidades e as possíveis formas de harmonizá-las, naquilo em que isso for possível, é uma tarefa que exige, como elemento integrador, a sobredita noção ampliada de "sustentabilidade". É este caráter integracionista/conglobante que deve pautar as ações concernentes ao trabalhar com a multiplicidade ínsita à matéria.

Logo, não se pode afastar as especificidades apontadas das discussões e propostas concernentes à diversificação da Matriz Energética Elétrica nacional, à ampliação da participação de qualquer das fontes que a compõem e a inserção de outras, ao papel que os diversos entes federados podem desempenhar nesta seara. Todavia, a citada noção não se queda na especificidade, pois, fazendo o caminho inverso, deve operar na integração de propostas e, nesse caminho, observar cada uma destas particularidades. É nesse sentido que, talvez, as considerações aqui tecidas possam fornecer indícios que, ao serem objetivados, possam contribuir ao atingimento deste desiderato.

\section{REFERÊNCIAS}

AGÊNCIA NACIONAL DE ENERGIA ELÉTRICA. Atlas de energia elétrica do Brasil. 3.ed. Brasília: ANEEL, 2008.

Atlas de energia eólica. Ano 2003?. Disponível em: <http://www.aneel.gov.br/aplica coes/atlas/pdf/06-energia_eolica\%283\%29.pd f>. Acesso em: 19 jul. 2014.

Energia solar. Disponível em: <www.aneel.gov.br/aplicacoes/atlas/pdf/03-Energia_S olar(3).pdf>. Acesso em: 14 jul. 2014.

Panorama do potencial eólico no Brasil. Disponível em: <www.aneel.gov.br/aplicac oes/atlas/energia_eolica /6_3.htm>. Acesso em: 14 jul. 2014.

Panorama do potencial de biomassa. Disponível em: <www.aneel.gov.br/biblioteca/ downloads/livros/panorama_biomassa.pdf>. Acesso: 14 jul. 2014.

Potencial hidrelétrico brasileiro. Disponível em: <www.aneel.gov.br/aplicacoes/atla s/energia_hidraulica/4_3.htm>. Acesso em: 14 jul. 2014.

BONAVIDES, Paulo. Curso de direito constitucional. 4. ed. São Paulo: Malheiros, 1993.

BRASIL. Constituição (1988). Constituição da República Federativa do Brasil de 1988. Disponível em: <http://www.planalto.gov.br/ccivil_03/constituicao/constitui\%C3\%A7ao.ht m>. Acesso em: 10 jan. 2015. 
CÂMARA DE COMERCIALIZAÇÃO DE ENERGIA ELÉTRICA. Disponível em: <http://www.ccee.org.br/portal/faces/pages_publico/onde-atuamos/fontes?_afrLoop=7540804 88098693\#\%40\%3F_afrLoop\%3D754080488098693\%26_adf.ctrl-state\%3Dn6nfmr2r9_4>. Acesso em: 14 jul. 2014.

COASE, Ronald H. O problema do custo social. In: SALAMA, Bruno Meyerhof. Direito e economia: textos escolhidos. São Paulo: Saraiva, 2010. p. 59-112.

COMPANHIA ENERGÉTICA DE MINAS GERAIS. CEMIG e governo estadual inauguram usina solar do Mineirão. Disponível em: <http://www.cemig.com.br/sites/ Imprensa/pt-br/Pag inas/usina-solar-doMineirao.aspx>. Acesso em: 25 jan. 2015.

COSTA, Igor Sporch da. Igualdade na diferença e tolerância. Viçosa: Editora UFV, 2007.

Para além das semelhanças: um ensaio sobre a autonomia e a simbiose entre o Direito Ambiental e o Direito Urbanístico. Revista dos tribunais, São Paulo, v. 946, p. 187-230, ago. 2014.

COUTINHO, Ronaldo do Livramento. Anotações críticas sobre o discurso da sustentabilidade. In: COUTINHO, Ronaldo do Livramento; AHMED, Flávio (Org.). Cidade, direito e meio ambiente: perspectivas críticas. Rio de Janeiro: Lúmen Juris, 2011. p. 1-12.

EMPRESA DE PESQUISA ENERGÉTICA (EPE). Balanço energético nacional 2013: ano base 2012. Rio de Janeiro: EPE, 2013.

Balanço energético nacional 2014: ano base 2013. Rio de Janeiro: EPE, 2013.

FERNANDES, Edésio. Do código civil de 1916 ao estatuto da cidade: algumas notas sobre a trajetória do direito urbanístico no Brasil. In: MATTOS, Liana Portilho (Org.). Estatuto da cidade comentado: lei n. 10.257, de 10 de julho de 2001. Belo Horizonte: Mandamentos, 2002. p. 11-52.

LEAL, Rogério Gesta. Gestão pública compartida e organizações sociais: um novo paradigma à administração pública. In: LEAL, Rogério Gesta; ARAUJO, Luiz Ernani Bonesso de (Orgs.). Direitos sociais \& políticas públicas: desafios contemporâneos. Santa Cruz do Sul: EDUNISC, 2001. p. 35-110. 
MALUF, Said. Teoria geral do Estado. 22. ed. revista atualizada pelo prof. Miguel Alfredo Malufe Neto. São Paulo: Saraiva, 1993.

MINISTÉRIO DO MEIO AMBIENTE. Energia maremotriz. Disponível em: <http://www.m ma.gov.br/clima/energia/energias-renovaveis/energia-maremotriz>. Acesso em: 14 jul. 2014.

OKADA, Denise Setsuko. Resíduos sólidos: novas perspectivas que se impõem. In: COUTINHO, Ronaldo do Livramento; AHMED, Flávio (Org.). Cidade, direito e meio ambiente: perspectivas críticas. Rio de Janeiro: Lúmen Juris, 2011.

PEREIRA, Marlene de Paula; SANTOS, Ângela Moulin Penalva. Desafios da política urbana: análise dos mecanismos de gestão do território que unificam a legislação ambiental e urbanística. In: ENCONTRO MINEIRO DE ADMINISTRAÇÃO PÚBLICA, ECONOMIA SOLIDÁRIA E GESTÃO SOCIAL - EMAPEGS. II, 2010, Viçosa. Anais eletrônicos Encontro Mineiro de Administração Pública, Economia Solidária e Gestão Social: Administração Pública, gestão social e Economia solidária: avanços e desafios. Viçosa: UFV, 2010. p. 302-313. Disponível em: <http://www.emap egs.ufv.br/docs/iiemapegsufv.pdf>. Acesso em: 01 set. 2013.

SANTOS, Ângela Moulin Penalva. Descentralização, participação e controle externo sobre os governos municipais no Brasil. Geo UERJ, Rio de Janeiro, a. 11, v. 2, n. 19, p. 17-43, 1ㅇ semestre de 2009.

SILVA, José Robson da. Paradigma biocêntrico: do patrimônio privado ao patrimônio ambiental. Rio de Janeiro: Renovar, 2002.

Trabalho enviado em 22 de março de 2015.

Aceito em 29 de abril de 2015. 